\title{
An integrated fuzzy model for evaluation and selection of mobile banking ( $m$-banking) applications using new fuzzy-BWM and fuzzy-TOPSIS
}

\author{
Pranith Kumar Roy ${ }^{1}$ (D) Krishnendu Shaw ${ }^{1}$
}

Received: 15 February 2021 / Accepted: 12 August 2021 / Published online: 24 August 2021

(c) The Author(s) 2021

\begin{abstract}
Mobile technology has revolutionised various business processes. Banking is one of them. Traditional banking operations are gradually changing with the introduction of efficient mobile technologies. Mobile banking (m-banking) has recently emerged as an innovative banking channel that provides continuous real-time customer service. It is expected that the market for $\mathrm{m}$-banking will expand in the near future. There are currently various types of $\mathrm{m}$-banking applications in the market. However, ranking and selecting efficient applications is difficult due to the involvement of multiple factors. As of now, very few studies have reported the m-banking application selection framework, left scope for further research. The current study proposes an m-banking application selection model based on a combined fuzzy best-worst method (fuzzy-BWM) and fuzzy Technique for Order of Preference by Similarity to Ideal Solution (fuzzy-TOPSIS). The research was carried out in several stages, beginning with the identification of potential factors and progressing to pair-wise comparisons and the final ranking of the applications. The fuzzy set theory was applied to handle the ambiguity of the decision maker. In the first stage, fuzzy-BWM was used to determine the weight of the factors. Further, fuzzy-TOPSIS was applied to rank the m-banking applications. The present study has adopted a new fuzzy BWM, which differs significantly from the existing fuzzy-BWM, to solve the nonlinearity problem of optimisation. The applicability of the proposed model has been demonstrated through a real-life case study. The efficacy of the model has been further examined by performing a sensitivity analysis. The study observed application functionality, convenience, and performance expectancy as significant factors in selecting an m-banking application, followed by performance quality, security, and compatibility. The proposed model can assist financial institutions and customers to overcome the challenges of choosing an appropriate m-banking application. The proposed model can be used to benchmark the m-banking applications in the market.
\end{abstract}

Keywords m-Banking $\cdot$ e-Banking $\cdot$ MCDM $\cdot$ Best-worst method $\cdot$ TOPSIS $\cdot$ Fuzzy set theory

\section{Introduction}

The banking sector has undergone a significant transformation due to the use of information and communication technologies (ICT) over time. The shift has been fueled by

Dedication: The author dedicates this article to his parents, Sh. Ashis Roy and Dulali Roy.

Pranith Kumar Roy

pranithroy@gmail.com

Krishnendu Shaw

shawkrishnendu@gmail.com

1 Department of Management Studies, Indian Institute of Technology (ISM) Dhanbad, Jharkhand 826004, India the consistent advancement of mobile technologies and the availability of low-cost smartphones. According to an International Telecommunication Union (ITU) study, approximately 6.68 and 4.1 billion people worldwide use mobile phones and access the mobile internet, respectively. Furthermore, nearly 3.2 billion people use smartphones today, and that number is expected to rise to 3.8 billion by 2021 (Statista, 2016). The financial sector can leverage information technology to deliver innovative services. One typical example is mobile banking (M-banking). M-banking is defined by Shaikh and Karjaluoto [1] as "a method of accessing bank services via mobile devices". The goal of $\mathrm{m}$-banking is to provide seamless financial services in a timely and efficient manner. A smartphone with the internet has become an integral part of daily life in this modern era. 
M-banking has the potential to change banking for customers and financial institutions in the twenty-first century [2]. It facilitates accessing various value-added services such as banking, education, and e-governance [3]. Improved ICT combined with efficient mobile devices (e.g., Android, iOS, Windows) can transform the traditional banking system into a portable banking system [4]. In the banking sector, the advancement of ICT has reduced financial transaction costs, simultaneously providing greater flexibility in time and physical movement [5].

Nowadays, financial institutions offer various services via m-banking and provide discounts to customers who use them. Several studies $[6,7]$ in the literature have reported on $\mathrm{m}$-banking adoption and its benefits. M-banking applications integrated with $3 \mathrm{G} / 4 \mathrm{G}$ technologies can perform various tasks, including mobile payment (m-payment), online shopping, ticket booking, trading, transacting, and many others [8]. M-banking applications have recently gained popularity among customers due to their ease of use and flexibility [6]. For example, an e-banking service must use a desktop or laptop terminal, whereas m-banking requires a mobile device with internet access only. As a result, m-banking allows customers to connect with banks more flexibly [9]. It is beneficial, particularly in rural areas where citizens have limited access to traditional banking services [10].

In comparison to the traditional banking system, the $\mathrm{m}$-banking channel increases productivity, lowers costs and improves customer satisfaction [11]. M-banking can significantly reduce physical bank visits and facilitate real-time wealth monitoring [12]. As of now, different researchers have reported various studies on m-banking [10]. These studies can be divided into three categories: (a) m-banking technology adoption, (b) m-banking application development, and (c) technology selection $[1,13,14]$. Among the areas mentioned above, m-banking application selection has received insufficient attention from researchers. Because of its growing popularity around the world, this field warrants further study.

To fill the research gaps, this paper proposes an m-banking selection model based on the combined fuzzy-BWM and fuzzy TOPSIS. This study combined fuzzy-TOPSIS with the most recent fuzzy-BWM method proposed by Dong et al. [15]. The purpose of this research is to identify the appropriate m-banking applications among the multiple alternatives. To the best of the author's knowledge, this is one of the few studies that used the newly developed fuzzy-BWM in conjunction with fuzzy-TOPSIS to select m-banking applications. The current study aims to answer the following research questions.

- What are the various factors that influence the selection of m-banking applications?
- What should be the weight of each factor in the selection of m-banking applications?

- How to evaluate each m-banking application and determine the final ranking?

This research aims to provide an MCDM framework for assessing numerous aspects that guide the choice of $\mathrm{m}$-banking applications for day-to-day activities based on one's needs and desires. This paper presents such a decisionmaking framework using the new fuzzy-BWM and fuzzy TOPSIS. To accomplish the task, the current study was carried out in multiple stages. Initially, the relevant factors were identified through a review of the literature. Further, a conceptual model has been developed with the help of academic and industry experts. The fuzzy-BWM was used to calculate the weights of the factors, and fuzzy-TOPSIS is applied to evaluate and rank m-banking applications. The present study also demonstrates how to deal with the subjectivity of decision-making. This study made an input by employing a hybrid methodology that combined the newly developed fuzzy-BWM proposed by Dong et al. [15] and fuzzy TOPSIS. The adopted method differs significantly from Guo and Zhao's [16] approach, in which the BWM [17] value was directly extended into a fuzzy environment and solved using non-linear programming. In the context of Guo and Zhao [16], obtaining a global optimal solution is difficult due to nonlinearity. This study used the Dong et al. method [15], which can easily handle the nonlinearity problems of fuzzy BWM, previously proposed by Guo and Zhao [16]. According to the author's knowledge, a combined method of newly developed fuzzy-BWM and fuzzy-TOPSIS for selecting m-banking applications has been rarely reported. The current study describes how to combine two different multi-criteria decision-making techniques to reach a meaningful solution.

The main reason for applying fuzzy-BWM is that it is more consistent than the existing MCDA techniques [17]. The consistency further improves when BWM is combined with fuzzy set theory $[15,16]$. At the same time, the fuzzyTOPSIS fulfils the primary purpose of identifying an alternative with respect to its ideal and negative ideal solution. This study is the first to apply the fuzzy-BWM to the field of $\mathrm{m}$-banking. The practical process requires less time and data than existing MCDAs. Second, this study makes an effort to improve the identification and selection of m-banking systems by incorporating thirty criteria to make them reliable and trustworthy. It combines easiness and riskiness aspects besides usefulness since focusing only on usefulness aspects may lead to an incorrect decision. Further, the normal BWM and TOPSIS based on crisp value may not tackle the practical decision making problem because the information is imprecise. Therefore, to overcome the problem and provide 
a solution to human uncertainty, the fuzzy sets theory has been applied.

The remainder of the article is arranged as follows. The second segment discusses the relevant literature. Section three focuses on the methodology of the study. Section four discusses the case study. Sections five and six present the findings, discussions, and sensitivity analysis, respectively. Finally, section seven presents the conclusion.

\section{Literature review}

This section discusses the relevant $\mathrm{m}$-banking literature. The goal of this study is to select an effective m-banking application from multiple alternatives. The entire literature has been reviewed in three sections. The first section discussed the fundamental concepts of m-banking and its evolution. The second segment demonstrates the use of multi-criteria decision-making techniques. The third section goes over the important factors to consider while choosing an m-banking application.

\section{M-banking and its evolution}

Banking is an essential service in human life. Nowadays, customers can interact with banks through various channels, including branch visits, automated teller machines (ATM), phone calls, internet banking, and m-banking [18]. However, m-banking is the most efficient and convenient way to access banking services. The concept of m-banking is relatively new in management literature, and the definition of m-banking varies significantly across published articles. According to Barnes and Corbitt [19], m-banking is "a channel through which a customer interacts with a bank via a mobile device, such as a mobile phone or personal digital assistant (PDA)." According to Clarke [20], m-banking is a "subset of e-banking or online banking that refers to the shift of conducting financial transactions from wired networks to wireless networks." M-banking is regarded as a subset of m-commerce.

On the other hand, m-commerce is considered a subset of e-commerce [21]. Electronic banking was first implemented using a landline telephone in the 1980s [22], and the concept of m-banking evolved from there. The Bank of Scotland in the United Kingdom was the first to offer e-banking services in 1983. Paybox, on the other hand, launched its m-banking service in early 1999 with the assistance of Deutsche Bank [1]. Initially, m-banking applications were only available in European countries [1]. These applications have percolated to various developing and underdeveloped countries. A few examples of "m-banking" are mobile payments, mobile finance, and mobile transfers [23]. Amin et al. [24] used pocket banking terminology to describe m-banking.
There exists a significant difference between e-banking and m-banking. E-banking employs online channels such as computers or laptops, whereas m-banking typically uses a mobile device [25].

Although mobile banking and internet banking offer similar services, banks frequently encourage customers to use $\mathrm{m}$-banking due to its flexibility and low operating costs [26]. Mobile phones have now outnumbered personal computers and laptop computers. As a result, m-banking may be a preferable tool compared to e-banking for both customers and financial institutions. It also contributes to developing stronger relationships between financial institutions and their customers [25]. Customers can use M-banking to perform a variety of banking tasks remotely, such as opening accounts and conducting cashless commercial transactions [27]. The traditional brick-and-mortar banking approach has certain drawbacks, like high operating costs, strict timing of operations, queuing issues, waste of time, and non-availability of services on holidays. On the other hand, M-banking can solve these issues in a cost-effective and real-time manner [28]. The adoption of $\mathrm{m}$-banking is beneficial not only for financial institutions but also for increasing household savings. According to the findings of Loaba [29], m-banking services can increase formal and informal household savings by $2-3 \%$. Ouma et al. [30] also discovered that m-Banking has a similar saving potential. According to Zhu et al. [31], $\mathrm{m}$-banking has enormous potential in rural development.

According to the World Bank 2020 report, m-banking offers millions of people a convenient and secure alternative channel for transactions. It also aids in the growth of cashless financial transactions. M-banking has enormous potential to contribute to the development of a cashless society. Banks are currently projecting m-banking as a regular service provider due to its significant growth potential [32]. According to a KPMG report [33], cashless transactions have increased significantly around the world. Digital transactions grew at a compound annual growth rate of $12.7 \%$ between 2016 and 21. A developing country's growth rate is substantially higher than that of a developed country. Even though m-banking has grown in popularity over the years, its adoption rate has been low. The majority of users only use m-banking to check their balances [34]. According to the Global Findex report, until 2017, approximately 52\% of account holders worldwide accessed digital banking services [35]. Despite the benefits, selecting appropriate m-banking applications is a challenge for decision-makers.

\section{Related studies on MCDM and selection of $\mathbf{m}$-banking applications}

The selection of alternatives against multiple criteria can be considered as a multi-criteria decision-making (MCDM) problem. A typical MCDM problem is often classified into 
two categories: MADM (multi-attribute decision making) and MODM (multi-objective decision making) [36]. The study of MCDM began in the 1950s and 1960s. After the 1990s, this field grew at an exponential rate [37]. A complex problem is frequently broken down into smaller pieces in MCDM. These variables are then used to create a decision hierarchy. After calculating the weight of each component, the individual components should be combined to reach a decision [38]. Because of their adaptability to complex problems, MCDM techniques have been used widely [39]. Various researchers over the years have proposed several MCDM techniques. A few examples are the analytic hierarchy process (AHP) [40], analytic network process (ANP) [41], BWM [17], Preference Ranking Organization Method for Enrichment of Evaluations (PROMETHEE) [39], TODIM (an interactive multi-criteria decision making), TOPSIS [42], VlseKriterijumska Optimizacija I Kompromisno Resenje (VIKOR) [43]. Although MCDM is a widely used method for dealing with complex systems, its efficacy is frequently called into question. Consistency is an essential aspect of the model's efficacy. The decision matrix must be consistent with increasing the matrix size during the decision-making process [17]. This section contains studies related to the use of MCDM in m-banking selection.

Mishra and Singh [44] proposed an MCDM framework based on AHP to select appropriate electronic banking channels (EBC) in the Indian context. The researchers identified twenty-six factors in four categories: demographics, technicality, serviceability, and intention. Ecer [45] suggested a model to evaluate Turkey's m-banking services. The author used hybrid MCDM with fuzzy-AHP and additive ratio evaluation for selecting $\mathrm{m}$-banking. The $\mathrm{m}$-banking services were assessed based on three criteria, such as perceived security features, usefulness, and ease of use. Kou et al. [46] used a combination of three MCDM methods to rank the clustering algorithms: VIKOR, TOPSIS, and data envelopment analysis (DEA). The authors ranked the algorithms by taking eleven performance measures into account. Liang et al. [47] conducted a study on the quality of internet banking websites in Ghana. Product quality, responsiveness, ease of use, security, and privacy were used to evaluate the websites. To calculate the weight of the identified factors, the authors used the Pythagorean fuzzy VIKOR technique. Further, TODIM was used to rank the websites. Gbongli et al. [48] developed a model for ranking m-banking operating systems based on various factors such as financial, performance, time, and privacy. The authors quantified the risks of m-banking and suggested areas where managers should focus their efforts. In Poland, Chmielarz and Zborowski [49] proposed a model for selecting the best e-banking channel using the COMET (characteristics objects method). The e-banking sites were evaluated based on twenty criteria and experts' opinions.
Chou and Cheng [50] proposed a hybrid system to rank the websites of Taiwan's top four accounting firms combining the VIKOR and ANP in a fuzzy setting. The website's qualities were evaluated against various information and service quality factors in their study. Fuzzy-ANP was used in their research to calculate the criteria weight, and fuzzy-VIKOR was used to prioritise the websites. Kaya and Kahraman [51] used an integrated methodology based on MCDM to evaluate e-banking websites using eight evaluation criteria. Their identified criteria were product quality, competence, reliability, receptiveness, access, ease of use, information, and security. The weights of the criteria were calculated using a combination of fuzzy-AHP and ELECTRE in the study. The research was carried out in the context of the Turkish banking industry.

\section{Factors to determine the adoption of $\mathrm{m}$-banking}

The selection of appropriate m-banking is a complex decision. Different factors can influence the decision maker's choice for selecting a preferred m-banking channel. The decision to choose an m-banking application is frequently affected by system information, products, services, and customer-related factors. Several studies [52-54] have identified various factors that can influence user acceptance of m-banking. Various researchers propose multiple theories in the literature to explain the adoption behaviour of new technology. Innovation diffusion theory (IDT), technology acceptance model (TAM), and unified theory of acceptance and usage of technology (UTAUT) are a few examples [55, 56]. The majority of studies have found that users frequently adopt technology if they perceive clear benefits regarding ease of use and usefulness [52]. Szopiski [57] identified thirteen criteria related to e-banking adoption in Poland. The author found that trust in banks, mobile phones, and internet service providers was a deciding factor in online banking's adoption. Furthermore, the author found convenience, usefulness, and safety as critical factors in technology adoption.

Shankar and Rishi [12] identified various aspects of $\mathrm{m}$-banking adoption. According to their findings, access and transaction convenience were critical considerations when deciding on m-banking. According to Oliveira et al. [27], behavioural and technological factors frequently play a crucial role in adopting m-banking applications. Among technical considerations, technology characteristics and performance expectancy play an essential role in m-banking selection. According to some studies, satisfaction and loyalty are essential factors in m-banking adoption [26]. Satisfaction has a direct impact on the decision to use a specific m-banking application. Furthermore, the application's system, information, and service quality influence m-banking adoption [18]. According to Gu et al. [58], the usefulness and ease of using technology are the determining factors for mobile 
payment. According to Al-Saedi et al. [59], trust, efficiency, expectancy, and social influence play a significant role in $\mathrm{m}$-payment adoption. Technology becomes user-friendly when the process is simple. In this context, the two most important criteria for technology adoption are ease of use and usefulness [53]. Another factor that influences the use of online banking is trust [4, 57]. Mehri et al. [60] discovered that a user's habits, trust, system privacy, and security influence their intention to use m-banking services. In their study, application performance anticipation emerged as a significant factor.

\section{Research gaps and novelty of the present study}

Based on the literature review, it can be conjectured that insufficient research has been performed on m-banking application selection. In literature, there are studies like selecting e-banking channels [44], m-banking services [45], ranking of the quality of internet banking websites [47], and m-banking operating systems [48]. However, none of the aforementioned research focused on selecting the best m-banking application. Further, none of them evaluated inclusive functionality components and responsiveness criteria, as well as security and reliability concerns for m-banking application selection. This study aims to solve a few research gaps in the field of m-banking adoption. M-banking selection falls under the category of the MCDM problem, and hence, it is critical to use a systematic decision-making approach to solve the problem holistically. Furthermore, a more precise approach needs to be devised for selecting m-banking applications. In addition there exists a research opportunity by applying combined MCDM methodology for solving m-banking selection problem. As per the author's knowledge, no studies have reported combined fuzzyBWM and fuzzy-TOPSIS methods for m-banking selection. Although combined fuzzy-BWM and fuzzy-TOPSIS method has been applied in other context; but the research adds value to the existing literature in terms of application in the area of m-banking. The research tries to explain how fuzzy-BWM and fuzzy-TOPSIS can be used to determine the criterion's weight, and rank the best $\mathrm{m}$-banking applications. The research also elaborates on how to triangulate the decisions of a panel of experts. The research also demonstrated how the present model can be applied in real world settings.

\section{Research methodology}

The selection of m-banking based on multiple criteria can be termed as an MCDM problem. In literature, scholars have paid close attention to the methodology mentioned above due to its ability to handle complex situations. Supplier selection [61], material selection [62], personnel selection
[63], technology selection [64], performance measurement [65], and financial decision making [66] are a few examples of MCDM applications. The decision about the problem described above is based on a set of factors, sub-factors, and alternatives. BWM is a relatively new concept among the various MCDM techniques. Several researchers have reported that BWM could perform better as compared to existing MCDM techniques in terms of consistency. The method has been widely used to solve MCDM problems in various fields [61, 67, 68]. Recently, BWM has been used in conjunction with various methodologies such as TOPSIS [61], VIKOR [67], and PROMETHEE [68]. Taking reference to the preceding researches, this study combines fuzzy-BWM and fuzzy-TOPSIS to address the m-banking selection problem. TOPSIS is also a widely used technique for ranking and evaluating alternatives in terms of criteria [69]. Fuzzy set theory was used in this study to deal with imprecise information $[66,70]$. Figure 1 depicts a graphical representation of the methodology.

In this research, initially, the relevant criteria and subcriteria were identified from the literature. Further, a few factors were chosen from the list of identified factors through consultation with experts. The fuzzy-BWM method was used in the second phase to calculate the weight of subjective criteria. Finally, in the third phase, fuzzy-TOPSIS was used to rank the m-banking applications.

\section{Best-worst method (BWM)}

In this study, BWM is used to determine the weight of the criteria and sub-criteria in a fuzzy environment. Rezaei (2015) proposed BWM, a relatively new MCDM technique [17]. It has successfully solved several MCDM problems, including project site selection [71], evaluating firm performance, airport service quality [61], and others [72]. In comparison to other MCDM techniques such as AHP and ANP, BWM is relatively easy to implement. The technique has advantages in terms of comparison numbers, consistency, and reliability [17]. BWM, for example, requires only $(2 n-3)$ pair-wise comparisons, whereas AHP requires $n(n-1)$ pair-wise comparisons. AHP results are inconsistent due to many pair-wise comparisons and extensive data set involvement [17]. Rezaei [17, 73] proved that BWM is more consistent than AHP.

In a typical decision-making process, the decisionmakers frequently face difficulty to express precise numbers $[74,75]$. As a result, decision-makers typically prefer to quantify subjective criteria using interval values [76]. Some researchers [15, 16, 76-81] have extended the original BWM into the fuzzy environment to deal with such ambiguity in human judgement. For example, Mou et al. [74] developed the traditional BWM into a group decision-based intuitionistic fuzzy multiplicative 
Fig. 1 The pictorial representation of the proposed methodology flow-chart

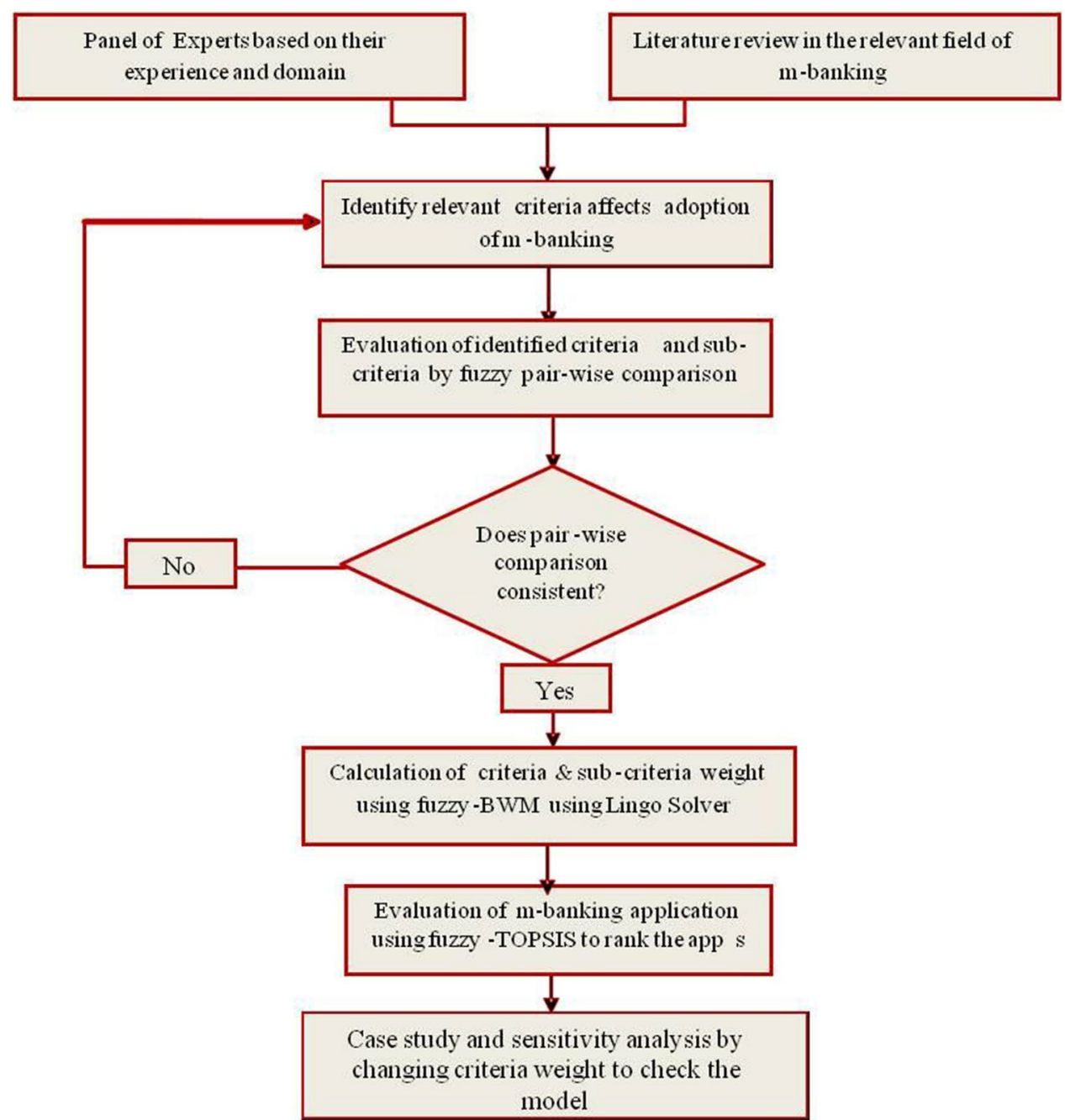

BWM (IFMBWM). Hafezalkotob and Hafezalkotob [77] proposed GIFBWM or group and Individual Fuzzy BWM to unite the group and individual decisions. To address the prototype design selection problem, Ijadi Maghsoodi et al. [78] proposed HBWFAD, a hierarchical group decision-making method based on BWM and axiomatic design principles in a fuzzy environment. Furthermore, Wan and Dong [79] proposed Intuitionistic Fuzzy-BWM to represent reference comparison using intuitionistic fuzzy values. Wan et al. [80] recently extended BWM to generalised interval-valued trapezoidal fuzzy BWM (GITrF BWM). The study found that GITrF BWM improves overall process consistency. Wan et al. [81] used trapezoidal interval type- 2 fuzzy sets to extend the original BWM into a fuzzy environment. The technique can be used in a variety of situations. The BWM was extended into a fuzzy environment by Hafezalkotob and Hafezalkotob [77]. The author demonstrated the group decision-making process by combining decision-makers' perspectives.
Ijadi Maghsoodi et al. [78] used a group decision-making approach to solve prototype design selection problems using fuzzy BWM and the axiomatic design principle.

Guo and Zhao [16] proposed TFN-based fuzzy-BWM. As compared to Rezaei's original BWM [17], the author claimed that their approach provides greater consistency. The study directly fuzzified all BWM parameters. Furthermore, the authors used non-linear programming to arrive at the solution. However, their method may not always be capable of providing a global optimal solution [15]. Dong et al. [15] proposed a new fuzzy-BWM based on TFNs to solve the problem. To find the best solution, the researchers used linear programming. This study employs the fuzzy-BWM proposed by Dong et al. [15] to determine the weight of the criteria. The following sections especially demonstrate fuzzy-BWM and fuzzy-TOPSIS in detail. Supplementary Appendix A contains the fundamental theories of fuzzy set theory. 


\section{Algorithm of fuzzy-BWM}

For applying the fuzzy-BWM method, identification of the factors should be made first. To obtain the weight of criteria, the pair-wise comparison should be carried out using linguistic terms. For multiple experts, the consensus of decisions must be converted into fuzzy numbers. Suppose there are " $\mathrm{n}$ " criteria to assess the alternatives. In this condition, total $(2 n-3)$ pair-wise comparisons should be carried out to calculate the weight of each criterion. The pair-wise comparison can be performed as per the fuzzy linguistic scale shown in Table 1.

The steps of the new fuzzy-BWM method, suggested by Dong et al. [15], are presented below:

a. Identify a set of factors $C_{1}, C_{2}, \ldots, C_{n}$ that affect the selection of alternatives.

b. Decide the Best $C_{B}$ (most important) and the Worst $C_{W}$ (least important) criteria from each criterion set.

c. Perform the fuzzy preference rating of the best criterion $C_{B}$ over other criteria to get the Best-to-Others weight vector as

$$
\tilde{A}_{B}=\left(\tilde{a}_{B 1}, \tilde{a}_{B 2}, \ldots, \tilde{a}_{B n}\right),
$$

where the fuzzy preference of the best criterion $C_{B}$ over other criterion $C_{j}$ is represented by $\tilde{a}_{B j}$

$j=1,2, \ldots, n$, and $\tilde{a}_{B B}=(1,1,1)$.

d. Similarly, perform fuzzy preference of all other criteria " $j$ " over Worst criterion $C_{W}$ to get others-to-worst vector as

$\tilde{A}_{w}=\left(\tilde{a}_{1 W}, \tilde{a}_{2 W}, \ldots, \tilde{a}_{n W}\right)$,

where the fuzzy preference of the other criterion $j$ " over Worst criterion $C_{W}$ is represented by $\tilde{a}_{j W}$

$j=1,2, \ldots, n$ and $\tilde{a}_{W W}=(1,1,1)$.

e. Decide the tolerance parameter values based on the interval from 1 to 9 . In this study, the global optimum solution was obtained at a tolerance parameter of 1 .

f. Based on the risk attitude, obtain the optimum fuzzy weights $\left(\tilde{w}_{1}^{*}, \tilde{w}_{2}^{*}, \tilde{w}_{3}^{*}, \ldots, \tilde{w}_{n}^{*}\right)$ of the criteria and the optimum objective value by maximising the satisfaction degree $\beta$.

In this study, the weight of the criteria is obtained from a neutral decision-maker as per the mixed approach-I of Dong et al. [16] by solving the following linear programming model.

$$
\begin{aligned}
& \max \beta \\
& \text { s.t. }\left\{\begin{array}{l}
1-\frac{w_{B}^{t}-w_{j}^{t} a_{B j}^{t}}{d_{j}^{t}} \geq \beta, 0 \leq w_{B}^{t}-w_{j}^{t} a_{B j}^{t} \leq d_{j}^{t}(j=1,2, \ldots, n ; \quad t=l, m, u) \\
1+\frac{w_{j}^{t}-w_{W}^{t} a_{j W}^{t}}{q_{j}^{t}} \beta,-q_{j}^{t} \leq w_{j}^{t}-w_{W}^{t} a_{j W}^{t} \leq 0(j=1,2, \ldots, n ; \quad t=l, m, u) \\
0 \leq \beta \leq 1 \\
\sum_{i=1}^{n} w_{i}^{m}=1, w_{j}^{u}+\sum_{i=1, i \neq j}^{n} w_{i}^{l} \leq 1, w_{j}^{l}+\sum_{i=1, i \neq j}^{n} w_{i}^{u} \geq 1 \quad(j=1,2, \ldots, n)
\end{array}\right\},
\end{aligned}
$$

Table 1 TFN scale using linguistic variables and corresponding consistency index [16]

\begin{tabular}{ll}
\hline Linguistic scale for the importance & TFN scale \\
\hline Equally Important (EI) & $(1,1,1)$ \\
Weakly Important (WI) & $(2 / 3,1,3 / 2)$ \\
Fairly Important (FI) & $(3 / 2,2,5 / 2)$ \\
Very Important(VI) & $(5 / 2,3,7 / 2)$ \\
Absolutely Important(AI) & $(7 / 2,4,9 / 2)$ \\
\hline
\end{tabular}

where $d_{j}^{t}$ and $q_{j}^{t}(j=1,2, \ldots, n ; t=l, m, u)$ are the values of tolerance parameters. Generally, $d_{j}^{t}$ and $q_{j}^{t}$ take any value from1 to 9 to get a unique optimal solution. In this study, for all the $d_{j}^{t}$ and $q_{j}^{t}$ have been considered as 1 .

The above fuzzy-BWM comparison is treated as fully consistent when $\tilde{a}_{B j} \times \tilde{a}_{j W}=\tilde{a}_{B W}$ for all $j$ However, during judgment, a decision-maker may not remain consistent for every criterion, and inconsistency arises when $\tilde{a}_{B j} \times \tilde{a}_{j W} \neq \tilde{a}_{B W}$ for all $j$. Hence, a fuzzy consistency ratio (FCR) needs to be calculated from the derived fuzzy deviation of the comparisons $\xi^{*}=\left(\xi^{l}, \xi^{m}, \xi^{u}\right)$ to check the pairwise comparison and the decision's overall consistency. 
g. To check the consistency of the comparisons, determine the fuzzy deviation of the comparisons $\xi^{*}=\left(\xi^{l}, \xi^{m}, \xi^{u}\right)$ as per Dong et al. [15].

$$
\begin{aligned}
& \xi^{\prime l}=\frac{1}{2 n} \sum_{j=1}^{n}\left(\left|w_{B}^{* l}-w_{j}^{* l} a_{B j}^{l}\right|+\left|w_{j}^{* l}-a_{j W}^{l} w_{w}^{* l}\right|\right), \\
& \xi^{\prime m}=\frac{1}{2 n} \sum_{j=1}^{n}\left(\left|w_{B}^{* m}-w_{j}^{* m} a_{B j}^{m}\right|+\left|w_{j}^{* m}-a_{j W}^{m} w_{w}^{* m}\right|\right), \\
& \xi^{\prime} u=\frac{1}{2 n} \sum_{j=1}^{n}\left(\left|w_{B}^{* u}-w_{j}^{* u} a_{B j}^{u}\right|+\left|w_{j}^{* u}-a_{j W}^{u} w_{w}^{* u}\right|\right) .
\end{aligned}
$$

Here, $\xi^{\prime l}, \xi^{\prime m}, \xi^{\prime} u$ represent the possible lower, middle and upper bound of fuzzy deviation $\xi^{*}$.

h. Finally, calculate the FCR from the fuzzy deviation $\xi^{*}=\left(\xi^{l}, \xi^{m}, \xi^{u}\right)$ using the below-mentioned formula [15], Dong et al. [15] provided a different fuzzy consistency index $(\mathrm{FCI})(\zeta)$ in Table 2 for different values of $\tilde{a}_{B W}$.

Fuzzy consistency ratio (FCR)

$$
=\frac{\tilde{\xi} *}{\text { Fuzzy consistency index }(\tilde{\zeta})} .
$$

i. Calculate the graded mean integration representation (GMIR) of the FCR, i.e. R (FCR), to check the consistency as per the following equation.

$$
R(\mathrm{FCR})=\frac{1}{6}\left(\frac{\xi^{* l}}{\zeta^{u}}+\frac{4 \xi^{* m}}{\zeta^{m}}+\frac{\xi^{* u}}{\zeta^{l}}\right) .
$$

The pair wise comparisons can be considered consistent if $R(\mathrm{FCR})=<1$, however, if $\mathrm{R}(\mathrm{FCR})=>0.1$, then the consistency of comparisons cannot be accepted [15].

\section{Fuzzy TOPSIS}

TOPSIS is a well-known MCDM technique developed by Hwang and Yoon in 1981 [42], to solve MCDM problems. TOPSIS is used to select the best alternative by comparing it to ideal solutions based on the shortest and farthest distances from positive and negative ideal solutions [82]. A positive ideal solution (PIS) maximises benefits while minimising costs, whereas a negative ideal solution (NIS) minimises benefits while increasing costs. TOPSIS has been used successfully to solve a variety of decision-making problems. Its mathematical simplicity and ease of use compared to other MCDM methods have established its popularity among researchers [70,83]. Because of its mathematical simplicity and ease of use, the technique has been successfully integrated with other MCDM methods [61, 84-87]. According to Hsieh et al. [88], if TOPSIS is used after another MCDM method, it can rank the alternatives better than a single MCDM. TOPSIS can also handle a larger number of alternatives than other MCDM methods [89]. However, in reallife decision-making, experts prefer to give interval values to deal with a fuzzy situation. Such evaluations for selecting the best alternative can be adequately explained by the fuzzy TOPSIS technique [90, 91]. Researchers such as Lima Junior et al. [89] have demonstrated that, unlike crisp TOPSIS and other MCDMs, fuzzy TOPSIS does not have a rank reversal problem, and an alternative remains the same with additional alternatives. Furthermore, fuzzy TOPSIS outperforms other popular MCDM, like fuzzy AHP [89], during the decision process. In a recent study, Roy and Shaw [92] applied fuzzy TOPSIS and BWM to develop a sustainable credit scoring technique. The study found that alternatives against subjective criteria are better evaluated using fuzzy-TOPSIS than normal TOPSIS. Until now, various researchers [61, 85, 86] have combined TOPSIS and fuzzy set theory to deal with uncertain scenarios. A few examples of fuzzy-TOPSIS applications include supplier selection [61], m-health application [85], measuring success factors in construction projects [86], and measuring performance [93]. The steps of the fuzzy TOPSIS algorithm are provided below.

Table 3 Linguistic scale and fuzzy numbers

\begin{tabular}{ll}
\hline Linguistic term & Fuzzy numbers \\
\hline Very Poor (VP) & $(0.0,0.0,0.3)$ \\
Poor (P) & $(0.1,0.3,0.5)$ \\
Medium (M) & $(0.3,0.5,0.7)$ \\
Good (G) & $(0.5,0.7,0.9)$ \\
Very Good (VG) & $(0.7,1.0,1.0)$ \\
\hline
\end{tabular}

Table 2 Fuzzy consistency indices (FCI) for fuzzy BWM [15]

\begin{tabular}{llllll}
\hline $\begin{array}{l}\text { Equally } \\
\text { important } \\
(\mathrm{EI})\end{array}$ & $\begin{array}{l}\text { Weakly } \\
\text { important } \\
(\mathrm{WI})\end{array}$ & Fairly important (FI) & Very important (VI) & Absolutely important (AI) \\
\hline$\tilde{a}_{B W}$ & $(1,1,1)$ & $(2 / 3,1,3 / 2)$ & $(3 / 2,2,5 / 2)$ & $(5 / 2,3,7 / 2)$ & $(7 / 2,4,9 / 2)$ \\
FCI & $(0,0,0)$ & $(0,0,1.36)$ & $(0.34,0.44,2.16)$ & $(0.71,1,4.29)$ & $(1.31,1.63,5.69)$ \\
\hline
\end{tabular}




\section{Algorithm of fuzzy-TOPSIS}

Step 1: When a set of alternatives $a_{i}(i=1,2, \ldots \ldots . m)$ needs to be evaluated with respect to identified criteria $c_{j}(j=1,2, \ldots \ldots n)$, it is required to form a fuzzy decision matrix $\tilde{a}_{i j}$.

$$
\tilde{A}_{i j}=\begin{gathered}
a_{1} \\
a_{2} \\
\vdots \\
a_{m}
\end{gathered}\left[\begin{array}{cccc}
c_{1} & c_{2} \ldots \ldots & c_{n} \\
x_{11} & x_{12} & \ldots & \ldots \\
x_{21} & x_{22} & \ldots & x_{1 n} \\
\vdots & \vdots & & x_{2 n} \\
x_{m 1} & x_{m 2} & \ldots & \vdots \\
x_{m n}
\end{array}\right]
$$

Step 2: In the current study, the linguistic scale using TFNs (triangular fuzzy numbers), as shown in Table 3, can be used to rate the alternatives [94]. The range of TFN should be between $[0,1]$ to avoid further normalisation.

Step 3: The decision matrix is multiplied with criteria weight $w_{i}$ to obtain the weighted normalised fuzzy-decision matrix.

$\tilde{W}=\left[\tilde{W}_{i j}\right]_{m \times n}$ where $i=1,2,3, \ldots, m, j=1,2,3, \ldots, n$ and $\tilde{W}_{i j}=\left[\tilde{A_{i j}}\right] \times w_{i}$.

Step 4: From the weighted fuzzy-decision matrix $\tilde{W}_{i j}$, the fuzzy positive ideal solution or FPIS $\left(F^{*}\right)$ and the fuzzy negative ideal solutions or FNIS $\left(F^{-}\right)$are determined.

$$
\begin{aligned}
F^{*} & =\left\{\tilde{v}_{l}^{*}, \ldots, \tilde{v}_{n}^{*}\right\}, \text { where } \tilde{v}_{l}^{*} \\
& =\left\{\max \left(\tilde{v}_{i j}\right) \text { if } j \varepsilon J ; \min \left(\tilde{v}_{i j}\right) \text { if } j \varepsilon J^{\prime}\right\}, j=1,2, \ldots, n . \\
F^{-} & =\left\{\tilde{v}_{l}^{-}, \ldots, \tilde{v}_{n}^{-}\right\}, \text {where } \tilde{v}_{l}^{-} \\
& =\left\{\min \left(\tilde{v}_{i j}\right) \text { if } j \varepsilon J ; \max \left(\tilde{v}_{i j}\right) \text { if } j \varepsilon J^{\prime}\right\}, j=1,2, \ldots, n
\end{aligned}
$$

Here, $J$ and $J^{\prime}$ represent positive and negative attributes, respectively.

Step 5: The Euclidian distances from the FPIS $\left(S_{a i}^{*}\right)$ and FNIS $\left(S_{a i}^{-}\right)$of the alternatives are determined as under:

$$
\begin{aligned}
& S_{a i}^{*}=\sum_{j=1}^{n} \sqrt{\left(v_{i j}-v_{j}^{*}\right)^{2}}, i=1,2,3, \ldots, m, \\
& S_{a i}^{-}=\sum_{j=1}^{n} \sqrt{\left(v_{i j}-v_{j}^{-}\right)^{2}}, i=1,2,3, \ldots, m .
\end{aligned}
$$

Step 6: The closeness index or similarity of alternatives $C_{a i}^{*}$ relative to the ideal solution is calculated as below:
$C_{a i}^{*}=\frac{S_{i}^{-}}{S_{a i}^{-}+S_{a i}^{*}}$, where $i=1,2,3, \ldots, m$.

Step 7: Finally, the alternatives are ranked based on their $C_{a i}^{*}$ value. An alternative with a maximum $C_{a i}^{*}$ is ranked as the best alternative, and the minimum $C_{a i}^{*}$ is ranked as the worst alternative.

\section{Evaluation of $\mathbf{m}$-banking using the proposed model}

This section discusses the case study of the proposed model. M-banking is increasingly becoming popular in both developing and developed countries. The real challenge, however, remains in selecting the appropriate $\mathrm{m}$-banking application. The selection of appropriate $\mathrm{m}$-banking applications is a difficult task that frequently includes multiple criteria. The problem can be formulated as an MCDM problem. This paper proposes an m-banking selection model that combines the recently developed fuzzy-BWM proposed by Dong et al. [15] and fuzzy-TOPSIS. The in-depth case study is discussed below.

\section{Identification of necessary factors for evaluation and selection of $\mathbf{m}$-banking}

It is imperative to identify potential m-banking adoption factors before selecting m-banking applications. The factors were identified by conducting a literature review in the relevant field. Various keywords, such as e-banking, m-banking, Technology Acceptance Model, and e-commerce, were used to search for relevant literature. Furthermore, a few identified factors have been dropped based on expert advice. A total of seven experts from industry and academia were chosen. Four of the seven respondents were from banks. The banking experts had extensive experience in the information technology sections of banks. Furthermore, three academic experts with experience in the field of operation research were identified. Although there were differences in responses initially, a consensus was reached after a thorough discussion [95]. Finally, ten criteria and thirty sub-criteria were agreed upon. Table 4 shows the specific factors.

Following the identification of criteria and sub-criteria, various m-banking applications were identified based on their popularity and market share. A survey was conducted to collect information on the m-banking applications. Supplementary Appendix B contains information on m-banking applications. M-banking applications were treated as alternatives in this study. The main objective of this study is to rank the identified alternatives based on the thirty sub-criteria organised into ten main criteria. 
Table 4 Identified factors that affect the adoption of m-banking applications

\begin{tabular}{|c|c|c|c|}
\hline Dimension & Criteria & Sub-criteria & References \\
\hline \multirow[t]{3}{*}{ Easiness } & Convenience (C1) & $\begin{array}{l}\text { Access convenience (S1) } \\
\text { Transactions convenience (S2) } \\
\text { Possession convenience (S3) }\end{array}$ & {$[12,96]$} \\
\hline & Simplicity (C2) & $\begin{array}{l}\text { Navigability (S4) } \\
\text { Searchability(S5) } \\
\text { Familiarity(S6) }\end{array}$ & {$[50,53]$} \\
\hline & Compatibility (C3) & $\begin{array}{l}\text { Method of banking affair (S7) } \\
\text { Aspects of banking activities (S8) } \\
\text { Compatible with lifestyle (S9) }\end{array}$ & [4] \\
\hline \multirow[t]{4}{*}{ Usefulness } & Expectancy (C4) & $\begin{array}{l}\text { Performance expectancy (S10) } \\
\text { Effort expectancy (S11) } \\
\text { Facilitating condition (S12) }\end{array}$ & {$[11,60]$} \\
\hline & Performance quality (C5) & $\begin{array}{l}\text { System (S13) } \\
\text { Service (S14) } \\
\text { Information (S15) }\end{array}$ & [97] \\
\hline & Functionality (C6) & $\begin{array}{l}\text { Features (S16) } \\
\text { Innovativeness (S17) } \\
\text { Customisation (S18) }\end{array}$ & [98] \\
\hline & Responsiveness (C7) & $\begin{array}{l}\text { Response time (S19) } \\
\text { Service quality (S20) } \\
\text { Customer service (S21) }\end{array}$ & {$[44]$} \\
\hline \multirow[t]{3}{*}{ Riskiness } & Security (C8) & $\begin{array}{l}\text { Authentication (S22) } \\
\text { Encryption (S23) } \\
\text { Privacy (S24) }\end{array}$ & {$[54,99]$} \\
\hline & Trust (C9) & $\begin{array}{l}\text { Banks offering the application (S25) } \\
\text { Cell phone producers (S26) } \\
\text { Telecommunication providers (S27) }\end{array}$ & [4] \\
\hline & Reliability (10) & $\begin{array}{l}\text { Reachability (S28) } \\
\text { Accuracy (S29) } \\
\text { Validity (S30) }\end{array}$ & {$[44,45,58]$} \\
\hline
\end{tabular}

A five-layer model is proposed (shown in Fig. 2). The primary goal of the research is to identify the best m-banking application. In this model, the goal is placed in the first layer. Criteria and sub-criteria are organised into the second, third, and fourth layers, respectively. Finally, on the fifth layer, the alternatives are placed. Fuzzy-BWM was used to determine the weight of factors in this study, and fuzzy TOPSIS was used to rank the applications.

\section{Computation of criteria weight using the fuzzy-BWM}

It was important to evaluate the weight of the factors after selecting the relevant factors and sub-factors. In this study, the importance of factors was calculated using the new fuzzy BWM proposed by Dong et al. [15]. Furthermore, the study was conducted from the perspective of a neutral decisionmaker, using the mixed approach-I described by Dong et al. [15]. In this study, the optimal global weight of criteria was computed using pair-wise comparisons at a tolerance parameter of 1 .

The detailed procedure for calculating the factor weight is shown below. The panel of experts from banks and academia were asked to choose the Best (most important) and Worst (least important) criteria from each set of main criteria and sub-criteria in this study. Subsequently, the panel was asked to perform fuzzy pair-wise comparisons using the linguistic scale suggested by Dong et al. [15]. The combined responses were used to create the fuzzy Best-to-Others and Othersto-Worst vectors. Similar comparisons were performed at different levels of the model. The pair-wise comparisons are shown in Tables 5, 6, 7, and 8 .

After obtaining the best-to-others and others-to-worst vectors for the main criteria, a linear programming model was developed in Lingo software as per Eq. 5. In this study, a tolerance parameter of 1 was adopted to get the unique global optimal solution. The fuzzy BWM algorithm is shown below. 


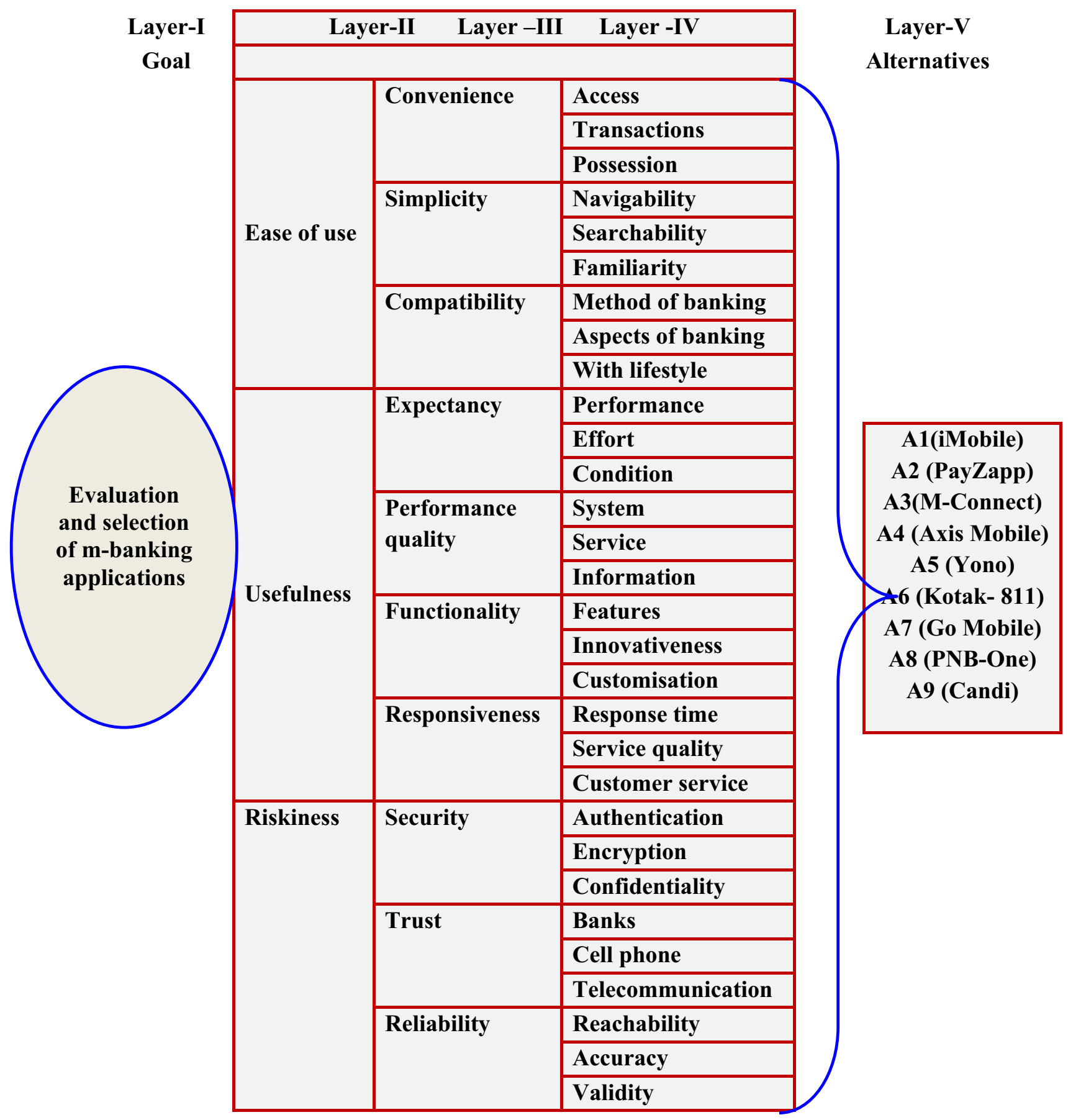

Fig. 2 The five layer decision hierarchy of m-banking selection applications

Table 5 The fuzzy linguistic pair-wise comparison for best over other dimensions

\begin{tabular}{llll}
\hline Other criteria & Riskiness & Ease of user & Usefulness \\
\hline $\begin{array}{l}\text { Best criteria } \\
\text { Usefulness }\end{array}$ & AI & FI & EI \\
\hline
\end{tabular}

Table 6 The fuzzy linguistic pair-wise comparison for other over worst dimension

\begin{tabular}{ll}
\hline Worst criteria & $\begin{array}{l}\text { Industry } \\
\text { evalua- } \\
\text { tion }\end{array}$ \\
\hline Other criteria & \\
Riskiness & EI \\
Ease of use & FI \\
Usefulness & AI \\
\hline
\end{tabular}


Table 7 Fuzzy best over other vectors for dimension

Other criteria

Riskiness

Ease of user

Usefulness

Best criteria

Usefulness

$(7 / 2,4,9 / 2)$

$(2 / 3,1,3 / 2)$

$(1,1,1)$

Table 8 Fuzzy other over worst vectors for dimension

\begin{tabular}{ll}
\hline Worst criteria & Riskiness \\
\hline Other criteria & \\
Riskiness & $(1,1,1)$ \\
Ease of use & $(3 / 2,2,5 / 2)$ \\
Usefulness & $(7 / 2,4,9 / 2)$ \\
\hline
\end{tabular}

The global optimal fuzzy weights $\left(\tilde{w}_{1}, \tilde{w}_{2}, \tilde{w}_{3}\right)$ were obtained by solving the linear programming model shown in Eq. 18 in Lingo 11.0. The experiments were carried out in a Dell Core i5 processor with an 8 GB Ram. Further, the crisp weights, i.e., GMIR of fuzzy weights, were calculated using Eq. 10. The fuzzy weight, crisp weight, fuzzy deviations $\xi^{*}=\left(\xi^{l}, \xi^{m}, \xi^{u}\right)$, and GMIR of the fuzzy consistency ratio, i.e., $\mathrm{R}(\mathrm{FCR})$, are shown in Table 9.

The FCR was calculated from the fuzzy deviations $\tilde{\xi} *$ $(0.038,0.071,0.102)$ and fuzzy consistency index (FCI) $(1.31,1.63,5.69)$ shown in Table 2 using Eqs. 9 and 10. The $R(\mathrm{FCR})$ was observed at 0.04 , which is very close to zero, satisfying the consistency requirement suggested by Dong et al. [15].

After obtaining the weight of the different dimensions, similar experiments were carried out for sub-criteria. In this

$\operatorname{Max} \beta$;

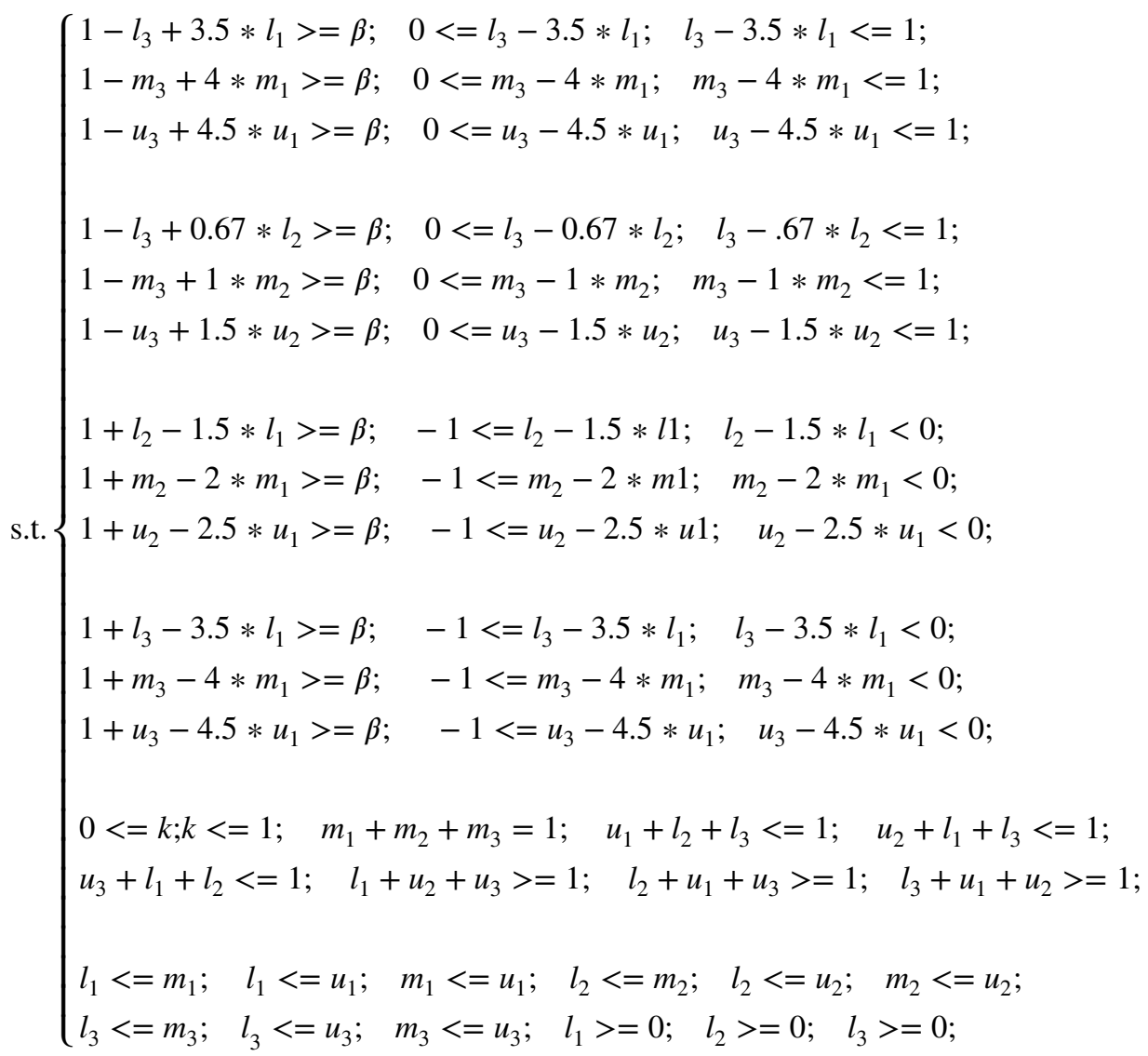

Table 9 Optimal fuzzy weight, crisp weight, and fuzzy consistency ratio of factors

\begin{tabular}{llll}
\hline Criteria & Ease of user & Usefulness & Riskiness \\
\hline Fuzzy weight & $(0.081,0.142,0.204)$ & $(0.000,0.285,0.510)$ & $(0.285,0.571,0.918)$ \\
Crisp weight & 0.142 & 0.275 & 0.581 \\
$\tilde{\xi} *$ and R(FCR $)$ & $(0.038,0.071,0.102) 0.714$ & & \\
\hline
\end{tabular}


Table 10 Final local and global weight of dimensions, main criteria and sub-criteria

\begin{tabular}{|c|c|c|c|c|c|c|c|}
\hline Dimensions & $\begin{array}{l}\text { Weight of } \\
\text { dimension }\end{array}$ & Main criteria & $\begin{array}{l}\text { Local weight } \\
\text { of main } \\
\text { criteria }\end{array}$ & $\begin{array}{l}\text { Global weight } \\
\text { of main criteria }\end{array}$ & Sub-criteria & $\begin{array}{l}\text { Local weight } \\
\text { of sub-criteria }\end{array}$ & Global Weight \\
\hline \multirow[t]{9}{*}{ Ease of use (E) } & \multirow[t]{9}{*}{0.2755} & \multirow[t]{3}{*}{ Convenience (C1) } & \multirow[t]{3}{*}{0.6704} & \multirow[t]{3}{*}{0.1847} & Access (S1) & 0.1120 & 0.0207 \\
\hline & & & & & Transactions (S2) & 0.6587 & 0.1217 \\
\hline & & & & & Possession (S3) & 0.2292 & 0.0423 \\
\hline & & \multirow[t]{3}{*}{ Simplicity (C2) } & \multirow[t]{3}{*}{0.1452} & \multirow[t]{3}{*}{0.0400} & Navigability(S4) & 0.6667 & 0.0267 \\
\hline & & & & & Searchability (S5) & 0.2222 & 0.0089 \\
\hline & & & & & Complexity (S6) & 0.1029 & 0.0041 \\
\hline & & \multirow[t]{3}{*}{ Compatibility (C3) } & \multirow[t]{3}{*}{0.1843} & \multirow[t]{3}{*}{0.0508} & $\begin{array}{l}\text { Method of banking } \\
\text { (S7) }\end{array}$ & 0.5000 & 0.0254 \\
\hline & & & & & $\begin{array}{l}\text { Aspects of banking } \\
\text { (S8) }\end{array}$ & 0.2476 & 0.0126 \\
\hline & & & & & With life style (S9) & 0.2523 & 0.0128 \\
\hline \multirow[t]{12}{*}{ Usefulness (U) } & \multirow[t]{12}{*}{0.5816} & \multirow[t]{3}{*}{$\begin{array}{l}\text { Performance expec- } \\
\text { tancy (C4) }\end{array}$} & \multirow[t]{3}{*}{0.2373} & \multirow[t]{3}{*}{0.1380} & $\begin{array}{l}\text { Performance expec- } \\
\text { tancy (S10) }\end{array}$ & 0.6980 & 0.0963 \\
\hline & & & & & $\begin{array}{l}\text { Effort expectancy } \\
\text { (S11) }\end{array}$ & 0.2000 & 0.0276 \\
\hline & & & & & $\begin{array}{l}\text { Facilitating condition } \\
\text { (S12) }\end{array}$ & 0.1053 & 0.0145 \\
\hline & & \multirow{3}{*}{$\begin{array}{l}\text { Performance quality } \\
\text { (C5) }\end{array}$} & \multirow[t]{3}{*}{0.1977} & \multirow[t]{3}{*}{0.1150} & System (S13) & 0.2041 & 0.0235 \\
\hline & & & & & Service (S14) & 0.6122 & 0.0704 \\
\hline & & & & & Information (S15) & 0.1837 & 0.0211 \\
\hline & & \multirow[t]{3}{*}{ Functionality (C6) } & \multirow[t]{3}{*}{0.4746} & \multirow[t]{3}{*}{0.2760} & Features (S16) & 0.1768 & 0.0488 \\
\hline & & & & & Innovativeness (S17) & 0.5836 & 0.1611 \\
\hline & & & & & Customisation (S18) & 0.2395 & 0.0661 \\
\hline & & \multirow[t]{3}{*}{ Responsiveness (C7) } & \multirow[t]{3}{*}{0.0873} & \multirow[t]{3}{*}{0.0508} & Response time (S19) & 0.1111 & 0.0056 \\
\hline & & & & & Service quality (S20) & 0.2222 & 0.0113 \\
\hline & & & & & $\begin{array}{l}\text { Customer service } \\
\text { (S21) }\end{array}$ & 0.6667 & 0.0338 \\
\hline \multirow[t]{9}{*}{ Riskiness (R) } & \multirow[t]{9}{*}{0.1428} & \multirow[t]{3}{*}{ Security (C8) } & \multirow[t]{3}{*}{0.5722} & \multirow[t]{3}{*}{0.0817} & Authentication (S22) & 0.1120 & 0.0092 \\
\hline & & & & & Encryption (S23) & 0.6587 & 0.0538 \\
\hline & & & & & Confidentiality (S24) & 0.2292 & 0.0187 \\
\hline & & Trust (C9) & 0.2717 & 0.0388 & Banks (S25) & 0.4883 & 0.0190 \\
\hline & & & & & Cell phone (S26) & 0.1364 & 0.0053 \\
\hline & & & & & $\begin{array}{l}\text { Telecommunication } \\
\text { (S27) }\end{array}$ & 0.3753 & 0.0146 \\
\hline & & Reliability (10) & 0.1560 & 0.0223 & Reachability (S28) & 0.2395 & 0.0053 \\
\hline & & & & & Accuracy (S29) & 0.5836 & 0.0130 \\
\hline & & & & & Validity (S30) & 0.1768 & 0.0039 \\
\hline
\end{tabular}

study, the global weight was calculated by multiplying the weight of dimensions with the local weight of the main criteria and sub-criteria. The final local and global weight of all the criteria is shown in Table 10.

Table 10 shows that the experts placed the greatest emphasis on the usefulness of m-banking applications $(0.5816)$, followed by ease of use $(0.2755)$ and riskiness (0.1428). The effectiveness of an m-banking application specifies how it can improve the users' financial performance. On the other hand, ease of use refers to how quickly and easily an m-banking application can be learned.
Furthermore, among the main criteria for selecting an m-banking application, functionality (C6) has emerged as the most important, followed by convenience (C1), expectancy (C4), performance quality (C5), and security (C8). The global weight of sub-criteria was calculated by multiplying the local importance of the main criteria by the weight of sub-criteria. Innovativeness (0.1610), transaction convenience (0.1216), performance expectancy (0.096), service quality (0.0704), customisation (0.066), and encryption (0.0538) emerged as significant factors with a weight of greater than $5 \%$ in the fuzzy BWM evaluation. Application innovation and transaction 
Table 11 Rating of m-banking applications using the fuzzy linguistic term used in fuzzy TOPSIS

\begin{tabular}{|c|c|c|c|c|c|c|c|c|c|}
\hline & A1 (iMobile) & A2 (PayZapp) & $\begin{array}{l}\text { A3 } \\
\text { (M-Con- } \\
\text { nect) }\end{array}$ & $\begin{array}{l}\text { A4 (Axis } \\
\text { Mobile) }\end{array}$ & A5 (Yono) & $\begin{array}{l}\text { A6 } \\
\text { (Kotak- } \\
811 \text { ) }\end{array}$ & $\begin{array}{l}\text { A7 (Go } \\
\text { Mobile) }\end{array}$ & A8 (PNB-One) & A9 (Candi) \\
\hline S1 & VG & VG & M & VG & G & G & G & G & $\mathrm{G}$ \\
\hline S2 & G & VG & G & G & G & $\mathrm{G}$ & M & $\mathrm{G}$ & G \\
\hline S3 & M & VG & $\mathrm{G}$ & G & VG & G & M & VG & $\mathrm{G}$ \\
\hline S4 & VG & VG & $\mathrm{G}$ & VG & G & VG & G & $\mathrm{G}$ & $\mathrm{G}$ \\
\hline S5 & VG & VG & $\mathrm{G}$ & VG & VG & VG & G & $\mathrm{G}$ & G \\
\hline S6 & $\mathrm{G}$ & VG & $\mathrm{G}$ & M & $\mathrm{M}$ & M & M & M & M \\
\hline S7 & VG & G & G & VG & G & G & $\mathrm{G}$ & G & G \\
\hline S8 & $\mathrm{G}$ & VG & M & $\mathrm{G}$ & G & G & VG & G & G \\
\hline S9 & G & VG & M & VG & G & VG & $\mathrm{G}$ & G & $\mathrm{G}$ \\
\hline $\mathrm{S} 10$ & VG & VG & M & $\mathrm{G}$ & G & VG & G & G & VG \\
\hline S11 & G & VG & M & G & G & VG & G & G & $\mathrm{G}$ \\
\hline $\mathrm{S} 12$ & VG & VG & $\mathrm{G}$ & VG & G & VG & G & G & VG \\
\hline S13 & VG & VG & G & $\mathrm{G}$ & $\mathrm{G}$ & VG & $\mathrm{G}$ & $\mathrm{G}$ & $\mathrm{G}$ \\
\hline S14 & $\mathrm{G}$ & VG & $\mathrm{G}$ & $\mathrm{G}$ & $\mathrm{G}$ & VG & VG & $\mathrm{G}$ & $\mathrm{G}$ \\
\hline $\mathrm{S} 15$ & VG & $\mathrm{M}$ & $\mathrm{G}$ & $\mathrm{G}$ & VG & $\mathrm{G}$ & VG & $\mathrm{G}$ & $\mathrm{VG}$ \\
\hline S16 & VG & $\mathrm{G}$ & $\mathrm{G}$ & $\mathrm{G}$ & VG & $\mathrm{G}$ & $\mathrm{G}$ & $\mathrm{G}$ & $\mathrm{G}$ \\
\hline S17 & VG & VG & VG & $\mathrm{G}$ & VG & VG & $\mathrm{G}$ & $\mathrm{G}$ & VG \\
\hline S18 & $\mathrm{G}$ & VG & $\mathrm{G}$ & $\mathrm{G}$ & VG & VG & $\mathrm{G}$ & $\mathrm{G}$ & $\mathrm{G}$ \\
\hline S19 & VG & VG & $\mathrm{G}$ & $\mathrm{G}$ & VG & VG & $\mathrm{G}$ & $\mathrm{G}$ & $\mathrm{G}$ \\
\hline $\mathrm{S} 20$ & $\mathrm{G}$ & VG & $\mathrm{G}$ & VG & $\mathrm{G}$ & $\mathrm{G}$ & $\mathrm{G}$ & $\mathrm{G}$ & $\mathrm{G}$ \\
\hline $\mathrm{S} 21$ & VG & VG & $\mathrm{G}$ & VG & G & VG & $\mathrm{G}$ & $\mathrm{G}$ & VG \\
\hline $\mathrm{S} 22$ & VG & VG & VG & G & VG & $\mathrm{G}$ & $\mathrm{G}$ & VG & VG \\
\hline $\mathrm{S} 23$ & $\mathrm{VG}$ & VG & VG & $\mathrm{G}$ & VG & $\mathrm{G}$ & $\mathrm{G}$ & VG & $\mathrm{VG}$ \\
\hline S24 & $\mathrm{G}$ & VG & VG & $\mathrm{G}$ & VG & $\mathrm{G}$ & $\mathrm{G}$ & VG & VG \\
\hline $\mathrm{S} 25$ & VG & $\mathrm{G}$ & $\mathrm{G}$ & $\mathrm{G}$ & $\mathrm{G}$ & $\mathrm{G}$ & $\mathrm{G}$ & $\mathrm{G}$ & $\mathrm{G}$ \\
\hline S26 & $\mathrm{G}$ & $\mathrm{G}$ & $\mathrm{G}$ & $\mathrm{G}$ & $\mathrm{G}$ & $\mathrm{G}$ & $\mathrm{G}$ & $\mathrm{G}$ & $\mathrm{G}$ \\
\hline S27 & VG & $\mathrm{M}$ & $\mathrm{G}$ & $\mathrm{G}$ & $\mathrm{G}$ & $\mathrm{G}$ & $\mathrm{G}$ & VG & VG \\
\hline S28 & $\mathrm{G}$ & VG & VG & $\mathrm{G}$ & VG & $\mathrm{G}$ & $\mathrm{G}$ & VG & $\mathrm{G}$ \\
\hline S29 & $\mathrm{G}$ & VG & VG & $\mathrm{G}$ & VG & $\mathrm{G}$ & $\mathrm{G}$ & VG & $\mathrm{G}$ \\
\hline S30 & $\mathrm{G}$ & VG & VG & $\mathrm{G}$ & VG & $\mathrm{G}$ & $\mathrm{G}$ & VG & $\mathrm{G}$ \\
\hline
\end{tabular}

convenience are critical considerations when selecting an m-banking application. $\mathrm{R}(\mathrm{FCR})$ values were calculated for all pair-wise comparisons using the Dong et al. [15] specification. An effort was made to keep the $R(\mathrm{FCR})$ value below 0.10 , which confirmed the decision's consistency. The global weight of various criteria was then used in fuzzy TOPSIS to rank m-banking applications.

\section{Evaluation of $\mathbf{m}$-banking applications and determining the final rank}

The m-banking applications were evaluated against the identified factors after the weights of the criteria were determined. Seven $\mathrm{m}$-banking applications provided by Indian banks were used as alternatives in this study. The same experts were asked to assign a fuzzy preference weight to each application in relation to the identified factors. The linguistic terms (very good, good, medium, poor, and very poor) were used to evaluate the m-banking applications. The scale is shown in Table 3 [100]. If an application's performance in that area was found best, it was rated as very good. On the other hand, an application was rated as very poor when it was the worst in that category.

Table 11 depicts the linguistic comparative decision matrix.

After evaluating m-banking applications using fuzzy linguistic terms, the ratings were transformed into fuzzy numbers as per the linguistic scale shown in Table 3. The fuzzy evaluation matrix is shown in Table 12.

In the next step, the fuzzy evaluation matrix was multiplied with the corresponding sub-criteria weights shown in Table 10 derived by fuzzy-BWM. The weighted fuzzy decision matrix is depicted in Table 13. 
Table 12 Fuzzy Evaluation Matrix for the m-banking applications

\begin{tabular}{|c|c|c|c|c|c|c|c|c|c|}
\hline & A1 (iMobile) & A2 (PayZapp) & $\begin{array}{l}\text { A3 (M-Con- } \\
\text { nect) }\end{array}$ & $\begin{array}{l}\text { A4 (Axis } \\
\text { Mobile) }\end{array}$ & A5 (Yono) & $\begin{array}{l}\text { A6 (Kotak- } \\
811)\end{array}$ & $\begin{array}{l}\text { A7 (Go } \\
\text { Mobile) }\end{array}$ & $\begin{array}{l}\text { A8 (PNB- } \\
\text { One) }\end{array}$ & A9 (Candi) \\
\hline S1 & $(0.7,1.0,1.0)$ & $(0.7,1.0,1.0)$ & $(0.3,0.5,0.7)$ & $(0.7,1.0,1.0)$ & $(0.5,0.7,0.9)$ & $(0.5,0.7,0.9)$ & $(0.5,0.7,0.9)$ & $(0.5,0.7,0.9)$ & $(0.5,0.7,0.9)$ \\
\hline S2 & $(0.5,0.7,0.9)$ & $(0.7,1.0,1.0)$ & $(0.5,0.7,0.9)$ & $(0.5,0.7,0.9)$ & $(0.5,0.7,0.9)$ & $(0.5,0.7,0.9)$ & $(0.3,0.5,0.7)$ & $(0.5,0.7,0.9)$ & $(0.5,0.7,0.9)$ \\
\hline S3 & $(0.3,0.5,0.7)$ & $(0.7,1.0,1.0)$ & $(0.5,0.7,0.9)$ & $(0.5,0.7,0.9)$ & $(0.7,1.0,1.0)$ & $(0.5,0.7,0.9)$ & $(0.3,0.5,0.7)$ & $(0.7,1.0,1.0)$ & $(0.5,0.7,0.9)$ \\
\hline S4 & $(0.7,1.0,1.0)$ & $(0.7,1.0,1.0)$ & $(0.5,0.7,0.9)$ & $(0.7,1.0,1.0)$ & $(0.5,0.7,0.9)$ & $(0.7,1.0,1.0)$ & $(0.5,0.7,0.9)$ & $(0.5,0.7,0.9)$ & $(0.5,0.7,0.9)$ \\
\hline S5 & $(0.7,1.0,1.0)$ & $(0.7,1.0,1.0)$ & $(0.5,0.7,0.9)$ & $(0.7,1.0,1.0)$ & $(0.7,1.0,1.0)$ & $(0.7,1.0,1.0)$ & $(0.5,0.7,0.9)$ & $(0.5,0.7,0.9)$ & $(0.5,0.7,0.9)$ \\
\hline S6 & $(0.5,0.7,0.9)$ & $(0.7,1.0,1.0)$ & $(0.5,0.7,0.9)$ & $(0.3,0.5,0.7)$ & $(0.3,0.5,0.7)$ & $(0.3,0.5,0.7)$ & $(0.3,0.5,0.7)$ & $(0.3,0.5,0.7)$ & $(0.3,0.5,0.7)$ \\
\hline S7 & $(0.7,1.0,1.0)$ & $(0.5,0.7,0.9)$ & $(0.5,0.7,0.9)$ & $(0.7,1.0,1.0)$ & $(0.5,0.7,0.9)$ & $(0.5,0.7,0.9)$ & $(0.5,0.7,0.9)$ & $(0.5,0.7,0.9)$ & $(0.5,0.7,0.9)$ \\
\hline S8 & $(0.5,0.7,0.9)$ & $(0.7,1.0,1.0)$ & $(0.3,0.5,0.7)$ & $(0.5,0.7,0.9)$ & $(0.5,0.7,0.9)$ & $(0.5,0.7,0.9)$ & $(0.7,1.0,1.0)$ & $(0.5,0.7,0.9)$ & $(0.5,0.7,0.9)$ \\
\hline S9 & $(0.5,0.7,0.9)$ & $(0.7,1.0,1.0)$ & $(0.3,0.5,0.7)$ & $(0.7,1.0,1.0)$ & $(0.5,0.7,0.9)$ & $(0.7,1.0,1.0)$ & $(0.5,0.7,0.9)$ & $(0.5,0.7,0.9)$ & $(0.5,0.7,0.9)$ \\
\hline S10 & $(0.7,1.0,1.0)$ & $(0.7,1.0,1.0)$ & $(0.3,0.5,0.7)$ & $(0.5,0.7,0.9)$ & $(0.5,0.7,0.9)$ & $(0.7,1.0,1.0)$ & $(0.5,0.7,0.9)$ & $(0.5,0.7,0.9)$ & $(0.7,1.0,1.0)$ \\
\hline S11 & $(0.5,0.7,0.9)$ & $(0.7,1.0,1.0)$ & $(0.3,0.5,0.7)$ & $(0.5,0.7,0.9)$ & $(0.5,0.7,0.9)$ & $(0.7,1.0,1.0)$ & $(0.5,0.7,0.9)$ & $(0.5,0.7,0.9)$ & $(0.5,0.7,0.9)$ \\
\hline S12 & $(0.7,1.0,1.0)$ & $(0.7,1.0,1.0)$ & $(0.5,0.7,0.9)$ & $(0.7,1.0,1.0)$ & $(0.5,0.7,0.9)$ & $(0.7,1.0,1.0)$ & $(0.5,0.7,0.9)$ & $(0.5,0.7,0.9)$ & $(0.7,1.0,1.0)$ \\
\hline S13 & $(0.7,1.0,1.0)$ & $(0.7,1.0,1.0)$ & $(0.5,0.7,0.9)$ & $(0.5,0.7,0.9)$ & $(0.5,0.7,0.9)$ & $(0.7,1.0,1.0)$ & $(0.5,0.7,0.9)$ & $(0.5,0.7,0.9)$ & $(0.5,0.7,0.9)$ \\
\hline S14 & $(0.5,0.7,0.9)$ & $(0.7,1.0,1.0)$ & $(0.5,0.7,0.9)$ & $(0.5,0.7,0.9)$ & $(0.5,0.7,0.9)$ & $(0.7,1.0,1.0)$ & $(0.7,1.0,1.0)$ & $(0.5,0.7,0.9)$ & $(0.5,0.7,0.9)$ \\
\hline S15 & $(0.7,1.0,1.0)$ & $(0.3,0.5,0.7)$ & $(0.5,0.7,0.9)$ & $(0.5,0.7,0.9)$ & $(0.7,1.0,1.0)$ & $(0.5,0.7,0.9)$ & $(0.7,1.0,1.0)$ & $(0.5,0.7,0.9)$ & $(0.7,1.0,1.0)$ \\
\hline S16 & $(0.7,1.0,1.0)$ & $(0.5,0.7,0.9)$ & $(0.5,0.7,0.9)$ & $(0.5,0.7,0.9)$ & $(0.7,1.0,1.0)$ & $(0.5,0.7,0.9)$ & $(0.5,0.7,0.9)$ & $(0.5,0.7,0.9)$ & $(0.5,0.7,0.9)$ \\
\hline S17 & $(0.7,1.0,1.0)$ & $(0.7,1.0,1.0)$ & $(0.7,1.0,1.0)$ & $(0.5,0.7,0.9)$ & $(0.7,1.0,1.0)$ & $(0.7,1.0,1.0)$ & $(0.5,0.7,0.9)$ & $(0.5,0.7,0.9)$ & $(0.7,1.0,1.0)$ \\
\hline S18 & $(0.5,0.7,0.9)$ & $(0.7,1.0,1.0)$ & $(0.5,0.7,0.9)$ & $(0.5,0.7,0.9)$ & $(0.7,1.0,1.0)$ & $(0.7,1.0,1.0)$ & $(0.5,0.7,0.9)$ & $(0.5,0.7,0.9)$ & $(0.5,0.7,0.9)$ \\
\hline S19 & $(0.7,1.0,1.0)$ & $(0.7,1.0,1.0)$ & $(0.5,0.7,0.9)$ & $(0.5,0.7,0.9)$ & $(0.7,1.0,1.0)$ & $(0.7,1.0,1.0)$ & $(0.5,0.7,0.9)$ & $(0.5,0.7,0.9)$ & $(0.5,0.7,0.9)$ \\
\hline S20 & $(0.5,0.7,0.9)$ & $(0.7,1.0,1.0)$ & $(0.5,0.7,0.9)$ & $(0.7,1.0,1.0)$ & $(0.5,0.7,0.9)$ & $(0.5,0.7,0.9)$ & $(0.5,0.7,0.9)$ & $(0.5,0.7,0.9)$ & $(0.5,0.7,0.9)$ \\
\hline $\mathrm{S} 21$ & $(0.7,1.0,1.0)$ & $(0.7,1.0,1.0)$ & $(0.5,0.7,0.9)$ & $(0.7,1.0,1.0)$ & $(0.5,0.7,0.9)$ & $(0.7,1.0,1.0)$ & $(0.5,0.7,0.9)$ & $(0.5,0.7,0.9)$ & $(0.7,1.0,1.0)$ \\
\hline $\mathrm{S} 22$ & $(0.7,1.0,1.0)$ & $(0.7,1.0,1.0)$ & $(0.7,1.0,1.0)$ & $(0.5,0.7,0.9)$ & $(0.7,1.0,1.0)$ & $(0.5,0.7,0.9)$ & $(0.5,0.7,0.9)$ & $(0.7,1.0,1.0)$ & $(0.7,1.0,1.0)$ \\
\hline S23 & $(0.7,1.0,1.0)$ & $(0.7,1.0,1.0)$ & $(0.7,1.0,1.0)$ & $(0.5,0.7,0.9)$ & $(0.7,1.0,1.0)$ & $(0.5,0.7,0.9)$ & $(0.5,0.7,0.9)$ & $(0.7,1.0,1.0)$ & $(0.7,1.0,1.0)$ \\
\hline $\mathrm{S} 24$ & $(0.5,0.7,0.9)$ & $(0.7,1.0,1.0)$ & $(0.7,1.0,1.0)$ & $(0.5,0.7,0.9)$ & $(0.7,1.0,1.0)$ & $(0.5,0.7,0.9)$ & $(0.5,0.7,0.9)$ & $(0.7,1.0,1.0)$ & $(0.7,1.0,1.0)$ \\
\hline S25 & $(0.7,1.0,1.0)$ & $(0.5,0.7,0.9)$ & $(0.5,0.7,0.9)$ & $(0.5,0.7,0.9)$ & $(0.5,0.7,0.9)$ & $(0.5,0.7,0.9)$ & $(0.5,0.7,0.9)$ & $(0.5,0.7,0.9)$ & $(0.5,0.7,0.9)$ \\
\hline S26 & $(0.5,0.7,0.9)$ & $(0.5,0.7,0.9)$ & $(0.5,0.7,0.9)$ & $(0.5,0.7,0.9)$ & $(0.5,0.7,0.9)$ & $(0.5,0.7,0.9)$ & $(0.5,0.7,0.9)$ & $(0.5,0.7,0.9)$ & $(0.5,0.7,0.9)$ \\
\hline S27 & $(0.7,1.0,1.0)$ & $(0.3,0.5,0.7)$ & $(0.5,0.7,0.9)$ & $(0.5,0.7,0.9)$ & $(0.5,0.7,0.9)$ & $(0.5,0.7,0.9)$ & $(0.5,0.7,0.9)$ & $(0.7,1.0,1.0)$ & $(0.7,1.0,1.0)$ \\
\hline S28 & $(0.5,0.7,0.9)$ & $(0.7,1.0,1.0)$ & $(0.7,1.0,1.0)$ & $(0.5,0.7,0.9)$ & $(0.7,1.0,1.0)$ & $(0.5,0.7,0.9)$ & $(0.5,0.7,0.9)$ & $(0.7,1.0,1.0)$ & $(0.5,0.7,0.9)$ \\
\hline S29 & $(0.5,0.7,0.9)$ & $(0.7,1.0,1.0)$ & $(0.7,1.0,1.0)$ & $(0.5,0.7,0.9)$ & $(0.7,1.0,1.0)$ & $(0.5,0.7,0.9)$ & $(0.5,0.7,0.9)$ & $(0.7,1.0,1.0)$ & $(0.5,0.7,0.9)$ \\
\hline S30 & $(0.5,0.7,0.9)$ & $(0.7,1.0,1.0)$ & $(0.7,1.0,1.0)$ & $(0.5,0.7,0.9)$ & $(0.7,1.0,1.0)$ & $(0.5,0.7,0.9)$ & $(0.5,0.7,0.9)$ & $(0.7,1.0,1.0)$ & $(0.5,0.7,0.9)$ \\
\hline
\end{tabular}

A fuzzy positive ideal solution (FPIS) and a fuzzy negative ideal solution (FNIS) were identified from the matrix. The best and worst solutions in this study are denoted as very good (VG) and very poor (VP), respectively. The weighted matrix was used to calculate the FPIS and FNIS values for each factor. Equations 15 and 16 were used to calculate the Euclidean distances from the FPIS and FNIS, respectively. Finally, the $\mathrm{m}$-banking applications were ranked based on the closeness index $C_{a i}^{*}$ derived from $S_{a i}^{*}$ and $S_{a i}^{-}$using Eq. 17. M-banking application with the highest $C_{a i}^{*}$ was considered as best while the lowest $C_{a i}^{*}$ was regarded as the worst application.

\section{Results and discussions}

In terms of research purpose, design concepts, and problemsolving methods, the current study has been found practical. This study analyses factors for selecting the most desirable $\mathrm{m}$-banking apps from the standpoint of end-users, financial institutions, and regulators who can act to increase financial inclusion in unbanked regions. This study is descriptive and thorough in terms of the number of adopted variables, with a broad range of criteria that impact the adoption of m-banking. In this study, ten primary criteria and thirty sub-criteria for selecting an m-banking application were proposed. Following that, the weights of the criterion and sub-criteria were computed using the newly developed fuzzy-BWM. Table 10 displayed the fuzzy-BWM output as well as the optimum global weight of criteria for all thirty criteria in the m-banking selection problem. Finally, the fuzzy-TOPSIS 
Table 13 Fuzzy weighted evaluation matrix for the m-banking applications

\begin{tabular}{|c|c|c|c|c|c|c|c|c|c|}
\hline & A1 (iMobile) & A2 (PayZapp) & A3 (M-Connect) & $\begin{array}{l}\text { A4 (Axis } \\
\text { Mobile) }\end{array}$ & A5 (Yono) & A6 (Kotak-811) & A7 (Go Mobile) & A8 (PNB-One) & A9 (Candi) \\
\hline S1 & $(0.01,0.02,0.02)$ & $(0.01,0.02,0.02)$ & $(0.01,0.01,0.01)$ & $(0.01,0.02,0.02)$ & $(0.01,0.01,0.02)$ & $(0.01,0.01,0.02)$ & $(0.01,0.01,0.02)$ & $(0.01,0.01,0.02)$ & $(0.01,0.01,0.0$ \\
\hline S2 & $.06,0.09,0.11)$ & $(0.09,0.12,0.12)$ & $(0.06,0.09,0.11)$ & $(0.06,0.09,0.11)$ & $(0.06,0.09,0.11)$ & $(0.06,0.09,0.11)$ & $(0.04,0.06,0.09)$ & $(0.06,0.09,0.11)$ & $(0.06,0.09,0.11)$ \\
\hline S3 & $(0.01,0.06,0.09)$ & $(0.03,0.12,0.12)$ & $(0.02,0.09,0.11)$ & $(0.02,0.09,0.11)$ & $(0.03,0.12,0.12)$ & $(0.02,0.09,0.11)$ & $(0.01,0.06,0.09)$ & $(0.03,0.12,0.12)$ & $(0.02,0.09,0.11)$ \\
\hline S4 & $(0.02,0.03,0.03)$ & $(0.02,0.03,0.03)$ & $(0.01,0.02,0.02)$ & $(0.02,0.03,0.03)$ & $(0.01,0.02,0.02)$ & $(0.02,0.03,0.03)$ & $(0.01,0.02,0.02)$ & $(0.01,0.02,0.02)$ & $(0.01,0.02,0.02$ \\
\hline S5 & $(0.01,0.01,0.01)$ & $(0.01,0.01,0.01)$ & $(0,0.01,0.01)$ & $(0.01,0.01,0.01)$ & $(0.01,0.01,0.01)$ & $(0.01,0.01,0.01)$ & $(0,0.01,0.01)$ & $(0,0.01,0.01)$ & $(0,0.01,0.01)$ \\
\hline S6 & $(0,0,0)$ & $(0,0,0)$ & $(0,0,0)$ & $(0,0,0)$ & $(0,0,0)$ & $(0,0,0)$ & $(0,0,0)$ & $(0,0,0)$ & $(0,0,0)$ \\
\hline S7 & $(0.02,0.03,0.03)$ & $(0.01,0.02,0.02)$ & $(0.01,0.02,0.02)$ & $(0.02,0.03,0.03)$ & $(0.01,0.02,0.02)$ & $(0.01,0.02,0.02)$ & $(0.01,0.02,0.02)$ & $(0.01,0.02,0.02)$ & $(0.01,0.02,0.02$ \\
\hline S8 & $(0.01,0.01,0.01)$ & $(0.01,0.01,0.01)$ & $(0,0.01,0.01)$ & $(0.01,0.01,0.01)$ & $(0.01,0.01,0.01)$ & $(0.01,0.01,0.01)$ & $(0.01,0.01,0.01)$ & $(0.01,0.01,0.01)$ & $(0.01,0.01,0.01)$ \\
\hline S9 & $(0.01,0.01,0.01)$ & $(0.01,0.01,0.01)$ & & & & & & & $(0.01,0.01,0.01)$ \\
\hline S10 & $(0.07,0.1,0.1)$ & $(0.07,0.1,0.1)$ & $(0.03,0.05,0.07)$ & $(0.05,0.07,0.09)$ & $(0.05,0.07,0.09)$ & $(0.07,0.1,0.1)$ & $(0.05,0.07,0.09)$ & $(0.05,0.07,0.09)$ & $(0.07,0.1,0.1)$ \\
\hline S11 & $(0.01,0.02,0.02)$ & $(0.02,0.03,0.03)$ & $(0.01,0.01,0.02)$ & $(0.01,0.02,0.02)$ & $(0.01,0.02,0.02)$ & $(0.02,0.03,0.03)$ & $(0.01,0.02,0.02)$ & $(0.01,0.02,0.02)$ & $(0.01,0.02,0.02)$ \\
\hline S12 & $(0.01,0.01,0.01)$ & $(0.01,0.01,0.01)$ & $(0.01,0.01,0.01)$ & $(0.01,0.01,0.01)$ & $(0.01,0.01,0.01)$ & $(0.01,0.01,0.01)$ & $(0.01,0.01,0.01)$ & $(0.01,0.01,0.01)$ & $(0.01,0.01,0.01$ \\
\hline S13 & $(0.02,0.02,0.02)$ & $(0.02,0.02,0.02)$ & $(0.01,0.02,0.02)$ & $(0.01,0.02,0.02)$ & $(0.01,0.02,0.02)$ & $(0.02,0.02,0.02)$ & $(0.01,0.02,0.02)$ & $(0.01,0.02,0.02)$ & $(0.01,0.02,0.02)$ \\
\hline S14 & $(0.04,0.05,0.06)$ & $(0.05,0.07,0.07)$ & $(0.04,0.05,0.06)$ & $(0.04,0.05,0.06)$ & $(0.04,0.05,0.06)$ & $(0.05,0.07,0.07)$ & $(0.05,0.07,0.07)$ & $(0.04,0.05,0.06)$ & $(0.04,0.05,0.06$ \\
\hline S15 & $(0.01,0.02,0.02)$ & $(0.01,0.01,0.01)$ & $(0.01,0.01,0.02)$ & $(0.01,0.01,0.02)$ & $(0.01,0.02,0.02)$ & $(0.01,0.01,0.02)$ & $(0.01,0.02,0.02)$ & $(0.01,0.01,0.02)$ & $(0.01,0.02,0.02)$ \\
\hline S16 & $(0.03,0.05,0.05)$ & $(0.02,0.03,0.04)$ & $(0.02,0.03,0.04)$ & $(0.02,0.03,0.04)$ & $(0.03,0.05,0.05)$ & $(0.02,0.03,0.04)$ & $(0.02,0.03,0.04)$ & $(0.02,0.03,0.04)$ & $(0.02,0.03,0.04$ \\
\hline S17 & $(0.11,0.16,0.16)$ & $(0.11,0.16,0.16)$ & $(0.11,0.16,0.16)$ & $(0.08,0.11,0.15)$ & $(0.11,0.16,0.16)$ & $(0.11,0.16,0.16)$ & $(0.08,0.11,0.15)$ & $(0.08,0.11,0.15)$ & $(0.11,0.16,0.16$ \\
\hline S18 & $(0.03,0.05,0.06)$ & $(0.05,0.07,0.07)$ & $(0.03,0$ & $(0.03,0.05,0.06)$ & $(0.05,0.07,0.07)$ & $(0.05,0.07,0.07)$ & $(0.03,0.05,0.06)$ & $(0.03,0.05,0.06)$ & $.05,0.06$ \\
\hline S19 & $(0,0.01,0.01)$ & $(0,0.01,0.01)$ & $(0,0,0.01)$ & $(0,0,0.01)$ & $(0,0.01,0.01)$ & $(0,0.01,0.01)$ & $(0,0,0.01)$ & $(0,0,0.01)$ & $(0,0,0.01)$ \\
\hline S20 & $(0.01,0.01,0.01)$ & $(0.01,0.01,0.01)$ & $(0.01,0.01,0.01)$ & $(0.01,0.01,0.01)$ & $(0.01,0.01,0.01)$ & $(0.01,0.01,0.01)$ & $(0.01,0.01,0.01)$ & $(0.01,0.01,0.01)$ & $(0.01,0.01,0.01)$ \\
\hline S21 & $(0.02,0.03,0.03)$ & $(0.02,0.03,0.03)$ & $(0.02,0.02,0.03)$ & $(0.02,0.03,0.03)$ & $(0.02,0.02,0.03)$ & $(0.02,0.03,0.03)$ & $(0.02,0.02,0.03)$ & $(0.02,0.02,0.03)$ & $(0.02,0.03,0.03$ \\
\hline S22 & $(0.01,0.01,0.01)$ & $(0.01,0.01,0.01)$ & $(0.01,0.01,0.01)$ & $(0,0.01,0.01)$ & $(0.01,0.01,0.01)$ & $(0,0.01,0.01)$ & $(0,0.01,0.01)$ & $(0.01,0.01,0.01)$ & $(0.01,0.01,0.01)$ \\
\hline S23 & $(0.04,0.05,0.05)$ & $(0.04,0.05,0.05)$ & $(0.04,0.05,0.05)$ & $(0.03,0.04,0.05)$ & $(0.04,0.05,0.05)$ & $(0.03,0.04,0.05)$ & $(0.03,0.04,0.05)$ & $(0.04,0.05,0.05)$ & $(0.04,0.05,0.05$ \\
\hline S24 & $(0.01,0.01,0.02)$ & $(0.01,0.02,0.02)$ & $(0.01,0.02,0.02)$ & $(0.01,0.01,0.02)$ & $(0.01,0.02,0.02)$ & $(0.01,0.01,0.02)$ & $(0.01,0.01,0.02)$ & $(0.01,0.02,0.02)$ & $(0.01,0.02,0.02)$ \\
\hline S25 & $(0.01,0.02,0.02)$ & $(0.01,0.01,0.02)$ & $(0.01,0.01,0.02)$ & $(0.01,0.01,0.02)$ & $(0.01,0.01,0.02)$ & $(0.01,0.01,0.02)$ & $(0.01,0.01,0.02)$ & $(0.01,0.01,0.02)$ & $(0.01,0.01,0.02$ \\
\hline S26 & $(0,0,0)$ & $(0,0,0)$ & $(0,0,0)$ & $(0,0,0)$ & $(0,0,0)$ & $(0,0,0)$ & $(0,0,0)$ & $(0,0,0)$ & $(0,0,0)$ \\
\hline S27 & $(0.01,0.01,0.01)$ & $(0,0.01,0.01)$ & $(0.01,0.01,0.01)$ & $(0.01,0.01,0.01)$ & $(0.01,0.01,0.01)$ & $(0.01,0.01,0.01)$ & $(0.01,0.01,0.01)$ & $(0.01,0.01,0.01)$ & $(0.01,0.01,0.01)$ \\
\hline S28 & $(0,0,0)$ & $(0,0.01,0.01)$ & $(0,0.01,0.01)$ & $(0,0,0)$ & $(0,0.01,0.01)$ & $(0,0,0)$ & $(0,0,0)$ & $(0,0.01,0.01)$ & $(0,0,0)$ \\
\hline S29 & $(0.01,0.01,0.01)$ & $(0.01,0.01,0.01)$ & $(0.01,0.01,0.01)$ & $(0.01,0.01,0.01)$ & $(0.01,0.01,0.01)$ & $(0.01,0.01,0.01)$ & $(0.01,0.01,0.01)$ & $(0.01,0.01,0.01)$ & $(0.01,0.01,0.01)$ \\
\hline S30 & $(0,0,0)$ & $(0,0,0)$ & $(0,0,0)$ & $(0,0,0)$ & $(0,0,0)$ & $(0,0,0)$ & $(0,0,0)$ & $(0,0,0)$ & $(0,0,0)$ \\
\hline
\end{tabular}

Table 14 Weighted and unweighted fuzzy TOPSIS results of m-banking applications

\begin{tabular}{|c|c|c|c|c|c|c|c|c|}
\hline \multirow[t]{2}{*}{ m-banking application } & \multicolumn{4}{|c|}{ Weighted results } & \multicolumn{4}{|c|}{ Un-weighted results } \\
\hline & $S_{a i}^{*}$ & $S_{a i}^{-}$ & $C_{a i}^{*}$ & Rank & $S_{a i}^{*}$ & $S_{a i}^{-}$ & $C_{a i}^{*}$ & Rank \\
\hline A1(iMobile) & 0.0924 & 0.1829 & 0.664 & 3 & 2.8160 & 4.9715 & 0.638 & 2 \\
\hline A2 (PayZapp) & 0.0342 & 0.2440 & 0.877 & 1 & 1.5155 & 6.5790 & 0.813 & 1 \\
\hline A3(M-Connect) & 0.1832 & 0.0969 & 0.346 & 8 & 5.5559 & 2.6520 & 0.323 & 8 \\
\hline A4 (Axis Mobile) & 0.1751 & 0.1064 & 0.378 & 7 & 4.8202 & 3.5399 & 0.423 & 7 \\
\hline A5 (Yono) & 0.1105 & 0.1680 & 0.603 & 4 & 3.4701 & 4.6220 & 0.571 & 3 \\
\hline A6 (Kotak-811) & 0.0931 & 0.1845 & 0.665 & 2 & 3.7076 & 4.2972 & 0.537 & 4 \\
\hline A7 (Go Mobile) & 0.2126 & 0.0626 & 0.227 & 9 & 5.8143 & 2.0553 & 0.261 & 9 \\
\hline A8 (PNB-One) & 0.1692 & 0.1078 & 0.389 & 6 & 4.4045 & 3.5512 & 0.446 & 6 \\
\hline A9 (CANDI) & 0.1173 & 0.1586 & 0.575 & 5 & 4.2546 & 3.6000 & 0.458 & 5 \\
\hline
\end{tabular}

is used to pick and rank m-banking applications. Table 14 shows the final rankings of all the m-banking applications.

In this study, the Payzapp application (A2) with a $C_{a i}^{*}$ of 0.877 has emerged as the best $\mathrm{m}$-banking application. Similarly, go mobile (A7), with a $C_{a i}^{*}$ of 0.227 , has been ranked as the worst application. The sequence of the rank of m-banking applications was A2-A6-A1-A5-A9-A8-A4-A3-A7.

Interestingly, a difference in the $C_{a i}^{*}$ and corresponding ranking was found among the weighted and unweighted results. Hence, it can be conjectured that the weight of the factors has a significant impact on the selection of 
Fig. 3 Sensitivity analyses by varying criteria weights on the ranking of m-banking applications

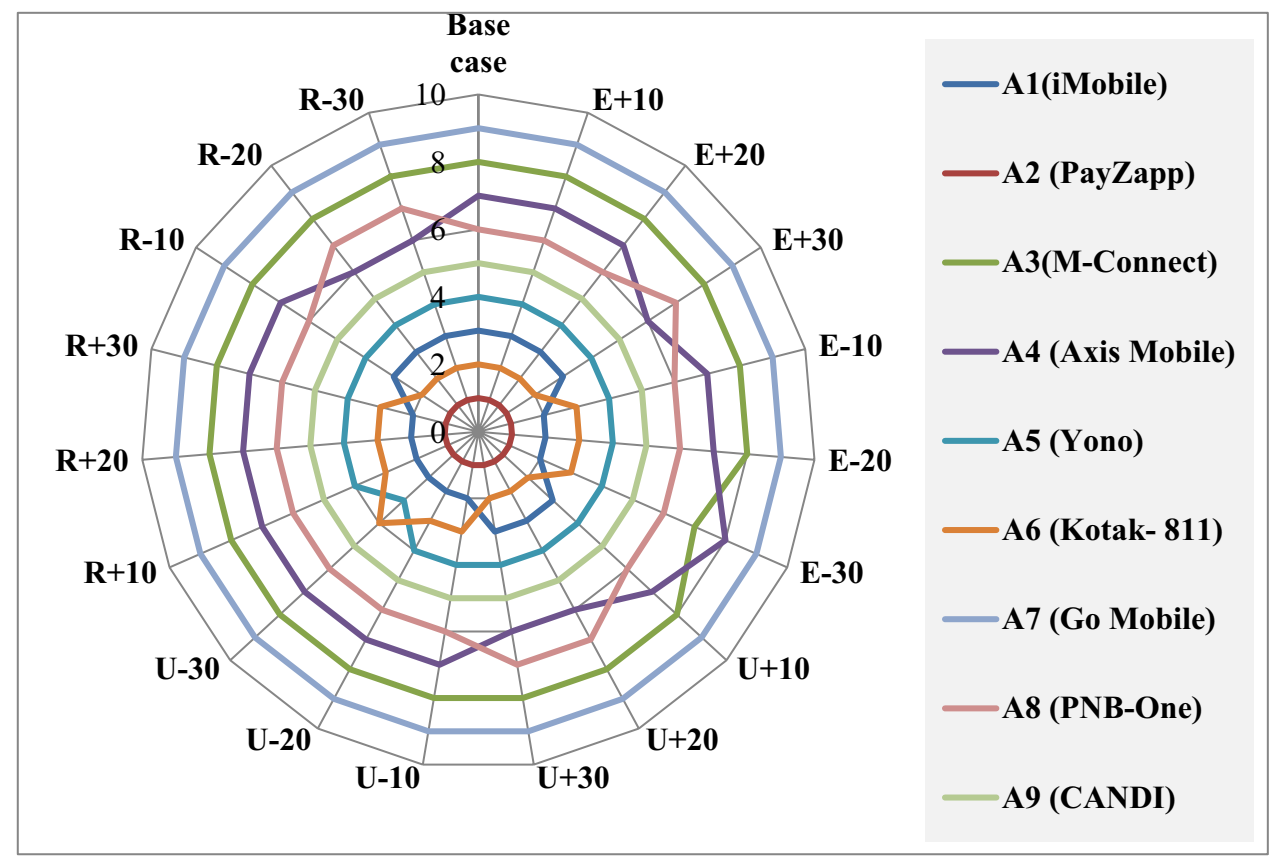

m-banking. According to Table 10, the usefulness of $\mathrm{m}$-banking applications and ease of use have emerged as the two most essential factors in selecting m-banking applications. Similarly, a decision-maker should pay due attention to convenience, functionality, expectancy, quality, and security when selecting m-banking applications. The current study's findings support the empirical findings of Singh and Srivastava [101], who pointed out that perceived ease of use and perceived security are both strong predictors of behavioural intention to use m-banking. The study findings also support Shankar and Rishi's [12] findings regarding the convenience of $\mathrm{m}$-banking.

\section{Sensitivity analysis}

The importance of various criteria primarily determines the selection of m-banking applications. As a result, it was intriguing to conduct the sensitivity analysis of the model. The primary goal of sensitivity analysis was to assess the impact of individual factors on the final decision. The sensitivity analysis was carried out by varying the weights of the factors. The weights of factors (ease of user $-\mathrm{E} \pm$; usefulness $-\mathrm{U} \pm$ and riskiness $-\mathrm{R} \pm$ ) were changed by $\pm 10 \%, \pm 20 \%$, and $\pm 30 \%$ once at a time. Changing weight once at a time ensures observing the effects of the factor on the overall decision. For example, how do usefulness, riskiness, and ease of use affect the final selection of m-banking applications? A total of eighteen experiments (six for each dimension) were carried out, and the results are presented in Fig. 3.
When the base scenario is compared to the $\mathrm{E}+30$ scenario, it can be seen that there is a significant difference in the ranking. For example, in the base scenario, the m-banking application's preference is found in the following order: A2-A6-A1-A5-A9-A8-A4-A3-A7. For the $\mathrm{E}+30$ scenario, the preference order has been changed to A2-A6-A1-A5-A9-A4-A8-A3-A7. If usability is prioritised, the A4 outperforms the A8. However, if the risk is prioritised in the $\mathrm{R}+20$ scenario, $\mathrm{A} 1$ ranks higher than A6 compared to the base scenario. If the risk factor (such as $\mathrm{R}+20$ ) is given higher importance, the sequence of preference of $\mathrm{m}$-banking applications should be A2-A1-A6-A5-A9-A8-A4-A3-A7.

A similar variation is observed when changing the weight of usefulness. In this study, the m-banking application A2 was found to be the most efficient application based on the importance of identified factors and subfactors. In this study, no significant ranking changes were observed for the A7 and A9 m-banking applications. Based on the sensitivity analysis, it can be assumed that the weights of the factors have a significant impact on the ranking of m-banking applications. A faulty or biased judgement can lead to the incorrect selection of m-banking applications.

\section{Comparative analysis}

Following the sensitivity analyses, a comparison with the existing literature was performed. Although a few studies [7, 45, 65, 102] addressed the selection of m-banking technologies, none of them addressed human judgement of 
uncertainty when making a decision. The proposed fuzzy model, which employs fuzzy-BWM and fuzzy-TOPSIS to select $\mathrm{m}$-banking applications, is unique in that it takes into account human uncertainty when selecting $\mathrm{m}$-banking applications. The current study identified thirty sub-criteria and classified them into ten main criteria. None of the existing literature compiled all of these factors into a single report. Our findings differ significantly from those of Zarifopoulos and Economides [102]. For example, the Zarifopoulos and Economides [102] framework did not consider the user's security and trust when selecting m-banking applications. In terms of methodology, the current study differs from Komlan et al. [7]. Komlan et al. [7] make no mention of the uncertainty of human judgement. This issue, however, has been addressed in the current study. Furthermore, the analysis differs significantly in terms of the number of factors used to evaluate m-banking applications.

\section{Conclusion}

M-banking has emerged as an effective tool for achieving a cashless society. An effective m-banking application can assist banks in offering their products at a low cost. Similarly, m-banking allows customers to receive seamless banking services twenty-four hours a day, seven days a week. Many financial institutions are now providing $\mathrm{m}$-banking applications. The real challenge, however, remains in selecting appropriate applications for customers. An attempt was made in this study to fill this research gap. In the current study, an MCDM-based m-banking application selection model in a fuzzy environment has been proposed. The fuzzy-BWM and fuzzy-TOPSIS methods were used in the study to rank the m-banking applications. For ranking different $\mathrm{m}$-banking applications, the model considered ten criteria and thirty sub-criteria. The goal of using BWM and TOPSIS in a fuzzy environment was to capture the ambiguity of a decision-making process. A case study was used to demonstrate the model's applicability. According to the authors' knowledge, very few studies have been reported the aforesaid factors for m-banking application selection.

This study has yielded a few significant findings. If the factors can be prioritised, then innovativeness and transaction convenience should be prioritised first when selecting m-banking applications. As a result, the data's performance, service, and encryption should be prioritised in the second level. When choosing an application at the third level, features and customer service should be prioritised. This study adds to the body of literature in a few ways. The current study addressed a real-world research problem that has not received much attention in management literature. Nonetheless, similar studies have been published on the subject of e-commerce and e-banking. However, specific research on this topic using the methodologies mentioned above is lacking in the literature. The adopted method successfully addressed the previous fuzzy-BWM method proposed by Guo and Zhao's nonlinearity problem [16]. The fuzzy-BWM methodology used can provide the global optimal solution while also ensuring consistency in the decision-making process. The proposed method could provide a reliable decision when it comes to selecting m-banking applications. The dimensions used in the study are unique. The model considered three important aspects of m-banking application selection: systems, information, and service providers. The sensitivity analysis adds a significant amount of knowledge to the body of literature. This type of sensitivity analysis is uncommon in e-banking or m-banking selection.

The proposed research has significant implications. To begin, a new set of factors for selecting an m-banking application has been identified. The study has tried to minimise the overlap of factors with existing studies. Second, this research explains how to create a comprehensive structure for selecting the most effective m-banking application. This study also made a methodological contribution by employing a hybrid methodology by combining the fuzzy BWM [15] and fuzzy TOPSIS. The current study describes how to combine two different multi-criteria decision-making techniques to reach a meaningful solution. Third, the proposed method also suggests how to deal with decision-making ambiguity.

The current study is practical from the perspective of the financial sector. The model can be applied in real life to select $\mathrm{m}$-banking applications. Financial institutions can use the model to rank the m-banking applications in the market. The proposed model can be used as a benchmarking tool for mobile banking applications. The study facilitates managers which factor is to be given higher importance for selecting m-banking applications. The scores of the various factors can be used as a quick reference when evaluating an m-banking application. Third, a manager can use different pair-wise comparisons to determine the weights of other factors based on their needs. Fourth, the model is very simple to implement on a daily basis. The current study is practical from the perspective of the end-users also. The model can be applied in real life to select the m-banking applications. Furthermore, this current study can facilitate the decisionmakers in choosing the most desirable m-banking applications. This study is descriptive and thorough regarding the number of adopted variables, with a broad range of criteria. The model is simple to implement in real life.

This study, like other studies, has a few limitations. During pair-wise comparisons, the experts' decisions may be biased. The research was carried out using a few m-banking applications. Dong et al. [15] proposed a newly developed fuzzy-BWM technique applied in this study, which is yet to 
be explored in other contexts. The following are the future research directions. Other methodologies, such as Bayesian BWM, VIKOR, and PROMETHEE, can be used to solve the proposed model. Further, the existing BWM may be extended into an entirely new context to solve the proposed model. Additional factors for evaluating m-banking applications could be considered in future studies. The case study in this study was conducted in the Indian context. However, it will be interesting to see how this model is implemented in other countries.

Supplementary Information The online version contains supplementary material available at https://doi.org/10.1007/s40747-021-00502-x.

Author contributions All authors have contributed equally to the study.

Availability of data and material Data used in this study is available with the corresponding author on request with reasonable time.

Code availability Code used in this study is available with the corresponding author on request at a reasonable time.

\section{Declarations}

Conflict of interest There are no competing/conflicts of interest.

Open Access This article is licensed under a Creative Commons Attribution 4.0 International License, which permits use, sharing, adaptation, distribution and reproduction in any medium or format, as long as you give appropriate credit to the original author(s) and the source, provide a link to the Creative Commons licence, and indicate if changes were made. The images or other third party material in this article are included in the article's Creative Commons licence, unless indicated otherwise in a credit line to the material. If material is not included in the article's Creative Commons licence and your intended use is not permitted by statutory regulation or exceeds the permitted use, you will need to obtain permission directly from the copyright holder. To view a copy of this licence, visit http://creativecommons.org/licenses/by/4.0/.

\section{References}

1. Shaikh AA, Karjaluoto H (2015) Mobile banking adoption: a literature review. Telemat Inform 32:129-142. https://doi.org/ 10.1016/j.tele.2014.05.003

2. Sharma SK, Govindaluri SM, Muharrami SM, Tarhini A (2017) A multi-analytical model for mobile banking adoption: a developing country perspective. Rev Int Bus Strateg 27:133-148. https://doi.org/10.1108/RIBS-11-2016-0074

3. Sharma SK, Al-Muharrami S (2018) Mobile banking adoption: key challenges and opportunities and implications for a developing country. In: Dwivedi Y (ed) Emerg. Mark. from a Multidiscip. Perspect. Adv. Theory Pract. Emerg. Mark., 1st edn. Springer, Cham, pp 75-86. https://doi.org/10.1007/ 978-3-319-75013-2_7

4. Hanafizadeh P, Behboudi M, Koshksaray AA, Tabar MJS (2014) Mobile-banking adoption by Iranian bank clients. Telemat Inform 31:62-78. https://doi.org/10.1016/j.tele.2012.11.001

5. Mishra V, Bisht SS (2013) Mobile banking in a developing economy: a customer-centric model for policy formulation.
Telecommun Policy 37:503-514. https://doi.org/10.1016/j.telpol.2012.10.004

6. Laukkanen T (2007) Internet vs mobile banking: comparing customer value perceptions. Bus Process Manag J 13:788-797. https://doi.org/10.1108/14637150710834550

7. Komlan G, Koffi D, Kingsford KM (2016) MCDM technique to evaluating mobile banking adoption in the togolese banking industry based on the perceived value : perceived benefit and perceived sacrifice factors. Int J Data Min Knowl Manag Process 6:37-56. https://doi.org/10.5121/ijdkp.2016.6304

8. Kim C, Mirusmonov M, Lee I (2010) An empirical examination of factors influencing the intention to use mobile payment Comput Human Behav 26:310-322. https://doi.org/10.1016/j. chb.2009.10.013

9. Aboelmaged M, Gebba TR (2013) Mobile banking adoption: an examination of technology acceptance model and theory of planned behavior. Int J Bus Res Dev 2:35-50. https://doi.org/10. 24102/ijbrd.v2i1.263

10. Malaquias RF, Hwang Y (2019) Mobile banking use: a comparative study with Brazilian and U.S. participants. Int J Inf Manag 44:132-140. https://doi.org/10.1016/j.ijinfomgt.2018.10.004

11. Alalwan AA, Dwivedi YK, Rana NP (2017) Factors influencing adoption of mobile banking by Jordanian bank customers: extending UTAUT2 with trust. Int J Inf Manag 37:99-110. https://doi.org/10.1016/j.ijinfomgt.2017.01.002

12. Shankar A, Rishi B (2020) Convenience matter in mobile banking adoption intention? Australas Mark J. https://doi.org/10. 1016/j.ausmj.2020.06.008

13. Tam C, Oliveira T (2017) Literature review of mobile banking and individual performance. Int J Bank Mark 35:1042-1065. https://doi.org/10.1108/IJBM-09-2015-0143

14. Adepoju SA, Oyefolahan IO, Abdullahi MB, Mohammed AA (2020) Multi-criteria decision-making based approaches in website quality and usability evaluation: a systematic review. J Inf Commun Technol 19:399-436. https://doi.org/10.32890/ jict2020.19.3.5

15. Dong J, Wan S, Chen SM (2021) Fuzzy best-worst method based on triangular fuzzy numbers for multi-criteria decisionmaking. Inf Sci (Ny) 547:1080-1104. https://doi.org/10.1016/j. ins.2020.09.014

16. Rezaei J (2015) Best-worst multi-criteria decision-making method. Omega 53:49-57. https://doi.org/10.1016/j.omega. 2014.11.009

17. Guo S, Zhao H (2017) Fuzzy best-worst multi-criteria decision-making method and its applications. Knowl Based Syst 121:23-31. https://doi.org/10.1016/j.knosys.2017.01.010

18. Tam C, Oliveira $T$ (2016) Understanding the impact of m-banking on individual performance: DeLone \& McLean and TTF perspective. Comput Human Behav 61:233-244. https://doi. org/10.1016/j.chb.2016.03.016

19. Barnes SJ, Corbitt B (2003) Mobile banking: concept and potential. Int J Mob Commun 1:273-288. https://doi.org/10. 1504/IJMC.2003.003494

20. Clarke I III (2001) Emerging value propositions for m-commerce. J Bus Strateg 18:133-148

21. Coursaris C, Hassanein K (2002) Understanding m-commerce: a consumer-centric model. Q J Electron Commer 3:247-272

22. Wazid M, Zeadally S, Das AK (2009) Mobile banking: evolution and threats: malware threats and security solutions. IEEE Consum Electron Mag 8:56-60. https://doi.org/10.1109/MCE. 2018.2881291

23. Donner J, Tellez CA (2008) Mobile banking and economic development: linking adoption, impact, and use. Asian J Commun 18:318-332. https://doi.org/10.1080/01292980802344190

24. Amin S, Hamid H, Tanakinjal MRA, Lada GH (2006) Undergraduate attitudes and expectations for mobile banking. J Int 
Bank Commerce 11:1-9. https://www.icommercecentral.com/ open-access/undergraduate-attitudes-and-expectations-formobile-banking-1-9.pdf

25. Laukkanen $\mathrm{T}$ (2016) Consumer adoption versus rejection decisions in seemingly similar service innovations: the case of the Internet and mobile banking. J Bus Res 69:2432-2439. https:// doi.org/10.1016/j.jbusres.2016.01.013

26. Thakur R (2014) What keeps mobile banking customers loyal? Int J Bank Mark 32:628-646. https://doi.org/10.1108/ IJBM-07-2013-0062

27. Oliveira T, Faria M, Thomas MA, Popovič A (2014) Extending the understanding of mobile banking adoption: when UTAUT meets TTF and ITM. Int J Inf Manag 34:689-703. https://doi. org/10.1016/j.ijinfomgt.2014.06.004

28. Hensmans M, Van Den Bosch FAJ, Volberda HW (2001) Clicks vs. bricks in the emerging online financial services industry. Long Range Plan 34:231-247. https://doi.org/10. 1016/S0024-6301(01)00030-9

29. Loaba S (2021) The impact of mobile banking services on saving behavior in West Africa. Glob Financ J. https://doi.org/10. 1016/j.gfj.2021.100620

30. Ouma SA, Odongo TM, Were M (2017) Mobile financial services and financial inclusion: is it a boon for savings mobilization? Rev Dev Financ 7:29-35. https://doi.org/10.1016/j.rdf. 2017.01.001

31. Zhu Q, Lyu Z, Long Y, Wachenheim CJ (2021) Adoption of mobile banking in rural China: impact of information dissemination channel. Socioecon Plan Sci. https://doi.org/10.1016/j.seps. 2021.101011

32. Nysveen H, Pedersen PE, Thorbjørnsen H (2005) Intentions to use mobile services: antecedents and cross-service comparisons. J Acad Mark Sci 33:330-346. https://doi.org/10.1177/00920 70305276149

33. Jain M (2019) Fintech in India-powering mobile payments. Capgeminin Consult Technol Outsourcing 53:5-13

34. Malaquias F, Malaquias R, Hwang Y (2018) Understanding the determinants of mobile banking adoption: a longitudinal study in Brazil. Electron Commer Res Appl 30:1-7. https://doi.org/10. 1016/j.elerap.2018.05.002

35. Demirgüç-Kun A, Klapper L, Singer D, Ansar S, Hess H (2017) The Global Findex Database 2017

36. Kahraman C, Onar SC, Oztaysi B (2015) Fuzzy multicriteria decision-making: a literature review. Int J Comput Intell Syst 8:637-666. https://doi.org/10.1080/18756891.2015.1046325

37. Köksalan M, Wallenius J, Zionts S (2011) The early history of MCDM. In: Mult. Criteria Decis. Mak. From Early Hist. to 21st Century. World Scientific Publishing Co. Pte Ltd., Singapore, pp 1-198. https://doi.org/10.1142/8042

38. Mardani A, Jusoh A, Nor KMD, Khalifah Z, Zakwan N, Valipour A (2015) Multiple criteria decision-making techniques and their applications-a review of the literature from 2000 to 2014. Econ Res Istraz 28:516-571. https://doi.org/10.1080/1331677X.2015. 1075139

39. Ishizaka A, Nemery P (2013) Multi-criteria decision analysis, 1st edn. Wiley, Chichester. https://doi.org/10.1002/9781118644898

40. Saaty TL (1977) A scaling method for priorities in hierarchical structures. J Math Psychol 15:234-281. https://doi.org/10.1016/ 0022-2496(77)90033-5

41. Saaty TL (2004) Fundamentals of the analytic network processdependence and feedback in decision-making with a single network. J Syst Sci Syst Eng 13:129-157. https://doi.org/10.1007/ s11518-006-0158-y

42. Hwang C-L, Yoon K (1981) Multiple attribute decision making methods and applications a state-of-the-art survey. Springer, Berlin.https://doi.org/10.1007/978-3-642-48318-9
43. Opricovic S, Tzeng GH (2004) Compromise solution by MCDM methods: a comparative analysis of VIKOR and TOPSIS. Eur J Oper Res 156:445-455. https://doi.org/10.1016/S0377-2217(03) 00020-1

44. Mishra V, Singh V (2015) Selection of appropriate electronic banking channel alternative: critical analysis using analytical hierarchy process. Int J Bank Mark 33:223-242. https://doi.org/ 10.1108/IJBM-09-2013-0099

45. Ecer F (2018) An integrated fuzzy AHP and ARAS model to evaluate mobile banking services. Technol Econ Dev Econ 24:670-695. https://doi.org/10.3846/20294913.2016.1255275

46. Kou G, Peng Y, Wang G (2014) Evaluation of clustering algorithms for financial risk analysis using MCDM methods. Inf Sci (Ny) 275:1-12. https://doi.org/10.1016/j.ins.2014.02.137

47. Liang D, Zhang Y, Xu Z, Jamaldeen A (2019) Pythagorean fuzzy VIKOR approaches based on TODIM for evaluating internet banking website quality of Ghanaian banking industry. Appl Soft Comput J 78:583-594. https://doi.org/10.1016/j.asoc.2019.03. 006

48. Gbongli K, Peng Y, Ackah O (2016) Selection and ranking of perceived risk associated with mobile banking in West Africa: an AHP approach from customers' perspective. Int J Sci Eng Res $7: 80-86$

49. Chmielarz W, Zborowski M (2018) On analysis of e-banking websites quality-comet application. Proc Comput Sci 126:2137-2152. https://doi.org/10.1016/j.procS.2018.07.238

50. Chou WC, Cheng YP (2012) A hybrid fuzzy MCDM approach for evaluating website quality of professional accounting firms. Expert Syst Appl 39:2783-2793. https://doi.org/10.1016/j.eswa. 2011.08.138

51. Kaya T, Kahraman C (2011) A fuzzy approach to e-banking website quality assessment based on an integrated AHP-ELECTRE method. Technol Econ Dev Econ 17:313-334. https://doi.org/10. 3846/20294913.2011.583727

52. Ho JC, Wu CG, Lee CS, Pham TTT (2020) Factors affecting the behavioral intention to adopt mobile banking: an international comparison. Technol Soc 63:101360. https://doi.org/10.1016/j. techsoc. 2020.101360

53. Liébana-Cabanillas F, Japutra A, Molinillo S, Singh N, Sinha N (2020) Assessment of mobile technology use in the emerging market: analyzing intention to use m-payment services in India. Telecommun Policy. https://doi.org/10.1016/j.telpol.2020. 102009

54. Sinigaglia F, Carbone R, Costa G, Zannone N (2020) A survey on multi-factor authentication for online banking in the wild. Comput Secur. https://doi.org/10.1016/j.cose.2020.101745

55. Venkatesh V, Morris MG, Davis GB, Davis FD (2003) User acceptance of information technology: toward a unified view. MIS Q 27:425-478. https://doi.org/10.2307/30036540

56. Davis FD, Bagozzi RP, Warshaw PR (1989) User acceptance of computer technology: a comparison of two theoretical models. Manag Sci 35:982-1003. https://doi.org/10.1287/mnsc.35.8.982

57. Szopiński TS (2016) Factors affecting the adoption of online banking in Poland. J Bus Res 69:4763-4768. https://doi.org/10. 1016/j.jbusres.2016.04.027

58. Gu JC, Lee SC, Suh YH (2009) Determinants of behavioral intention to mobile banking. Expert Syst Appl 36:11605-11616. https://doi.org/10.1016/j.eswa.2009.03.024

59. Al-Saedi K, Al-Emran M, Ramayah T, Abusham E (2020) Developing a general extended UTAUT model for M-payment adoption. Technol Soc 62:101293. https://doi.org/10.1016/j.techsoc. 2020.101293

60. Merhi M, Hone K, Tarhini A (2019) A cross-cultural study of the intention to use mobile banking between Lebanese and British consumers: extending UTAUT2 with file:///E:/IIT ISM/ Mbanking/Consumer Acceptance and Use of Information 
venkatesh2012.pdfsecurity, privacy and trust. Technol Soc 59:101151. https://doi.org/10.1016/j.techsoc.2019.101151

61. Gupta H, Barua MK (2017) Supplier selection among SMEs on the basis of their green innovation ability using BWM and fuzzy TOPSIS. J Clean Prod 152:242-258. https://doi.org/10.1016/j. jclepro.2017.03.125

62. Ijadi Maghsoodi A, Soudian S, Martínez L, Herrera-Viedma E, Zavadskas EK (2020) A phase change material selection using the interval-valued target-based BWM-CoCoMULTIMOORA approach: a case-study on interior building applications. Appl Soft Comput J 95:106508. https://doi.org/10.1016/j.asoc.2020. 106508

63. Ijadi Maghsoodi A, Riahi D, Herrera-Viedma E, Zavadskas EK (2020) An integrated parallel big data decision support tool using the W-CLUS-MCDA: a multi-scenario personnel assessment. Knowl Based Syst 195:105749. https://doi.org/10.1016/j.knosys. 2020.105749

64. Ijadi Maghsoodi A, Ijadi Maghsoodi A, Mosavi A, Rabczuk T, Zavadskas E (2018) Renewable energy technology selection problem using integrated H-SWARA-MULTIMOORA approach. Sustainability 10:4481. https://doi.org/10.3390/su10124481

65. Gbongli K, Xu Y, Amedjonekou KM, Kovács L (2020) Evaluation and classification of mobile financial services sustainability using structural equation modeling and multiple criteria decision-making methods. Sustainability 12:1-34. https://doi.org/10. 3390/su12041288

66. Roy PK, Shaw K (2021) A credit scoring model for SMEs using AHP and TOPSIS. Int J Finance Econ. https://doi.org/10.1002/ ijfe. 2425

67. Cheraghalipour A, Paydar MM, Hajiaghaei-Keshteli M (2018) Applying a hybrid BWM-VIKOR approach to supplier selection: a case study in the Iranian agricultural implements industry. Int J Appl Decis Sci 11:274-301. https://doi.org/10.1504/IJADS. 2018.092796

68. Ishizaka A, Resce G (2021) Best-worst PROMETHEE method for evaluating school performance in the OECD's PISA project. Socioecon Plann Sci 73:100799. https://doi.org/10.1016/j. seps.2020.100799

69. Nădǎban S, Dzitac S, Dzitac I (2016) Fuzzy TOPSIS: a general view. Proc Comput Sci 91:823-831. https://doi.org/10.1016/j. procs.2016.07.088

70. Salih MM, Zaidan BB, Zaidan AA, Ahmed MA (2019) Computers and Operations Research Survey on fuzzy TOPSIS state-of-the-art between 2007 and 2017. Comput Oper Res 104:207-227. https://doi.org/10.1016/j.cor.2018.12.019

71. Ijadi Maghsoodi A, Rasoulipanah H, Martínez López L, Liao $\mathrm{H}$, Zavadskas EK (2020) Integrating interval-valued multigranular 2-tuple linguistic BWM-CODAS approach with target-based attributes: Site selection for a construction project. Comput Ind Eng 139:106147. https://doi.org/10.1016/j.cie. 2019.106147

72. Rezaei J (2020) BWM bibliographical database, Best Worst Method, pp 1-21

73. Rezaei J (2016) Best-worst multi-criteria decision-making method: some properties and a linear model. Omega (United Kingdom) 64:126-130. https://doi.org/10.1016/j.omega.2015. 12.001

74. Salih MM, Zaidan BB, Zaidan AA, Ahmed MA (2019) Survey on fuzzy TOPSIS state-of-the-art between 2007 and 2017. Comput Oper Res 104:207-227. https://doi.org/10.1016/j.cor.2018. 12.019

75. Chan FTS, Kumar N, Tiwari MK, Lau HCW, Choy KL (2008) Global supplier selection: a fuzzy-AHP approach. Int J Prod Res 46:3825-3857. https://doi.org/10.1080/00207540600787200

76. Mou Q, Xu Z, Liao H (2016) An intuitionistic fuzzy multiplicative best-worst method for multi-criteria group decision making.
Inf Sci (Ny) 374:224-239. https://doi.org/10.1016/j.ins.2016.08. 074

77. Hafezalkotob A, Hafezalkotob A (2017) A novel approach for combination of individual and group decisions based on fuzzy best-worst method. Appl Soft Comput J 59:316-325. https://doi. org/10.1016/j.asoc.2017.05.036

78. Ijadi Maghsoodi A, Mosavat M, Hafezalkotob A, Hafezalkotob A (2019) Hybrid hierarchical fuzzy group decision-making based on information axioms and BWM: prototype design selection. Comput Ind Eng 127:788-804. https://doi.org/10.1016/j.cie. 2018.11.018

79. Wan S, Dong J (2021) A novel extension of best-worst method with intuitionistic fuzzy reference comparisons. IEEE Trans Fuzzy Syst. https://doi.org/10.1109/TFUZZ.2021.3064695

80. Wan S, Dong J, Chen S (2021) Fuzzy best-worst method based on generalized interval-valued trapezoidal fuzzy numbers for multicriteria decision-making. Inf Sci (Ny). 573:493-518. https://doi. org/10.1016/j.ins.2021.03.038

81. Wan SP, Chen ZH, Dong JY (2021) An integrated interval type-2 fuzzy technique for democratic-autocratic multi-criteria decision making. Knowl Based Syst 214:106735. https://doi.org/10. 1016/j.knosys.2020.106735

82. Ak MF, Gul M (2019) AHP-TOPSIS integration extended with Pythagorean fuzzy sets for information security risk analysis. Complex Intell Syst 5:113-126. https://doi.org/10.1007/ s40747-018-0087-7

83. Çoban V (2020) Solar energy plant project selection with AHP decision-making method based on hesitant fuzzy linguistic evaluation. Complex Intell Syst 6:507-529. https://doi.org/10.1007/ s40747-020-00152-5

84. Seiti H, Hafezalkotob A (2019) Developing the R-TOPSIS methodology for risk-based preventive maintenance planning: a case study in rolling mill company. Comput Ind Eng 128:622-636. https://doi.org/10.1016/j.cie.2019.01.012

85. Rajak M, Shaw K (2019) Evaluation and selection of mobile health (mHealth) applications by using AHP and fuzzy TOPSIS. Technol Soc 59:2. https://doi.org/10.1016/j.techsoc.2019.101186

86. Maghsoodi AI, Khalilzadeh M (2018) Identification and evaluation of construction projects' critical success factors employing fuzzy-TOPSIS approach. KSCE J Civ Eng 22:1593-1605. https:// doi.org/10.1007/s12205-017-1970-2

87. Chen P (2021) Effects of the entropy weight on TOPSIS. Expert Syst Appl 168:114186. https://doi.org/10.1016/j.eswa.2020. 114186

88. Joshi R, Banwet DK, Shankar R (2011) A Delphi-AHP-TOPSIS based benchmarking framework for performance improvement of a cold chain. Expert Syst Appl 38:10170-10182. https://doi. org/10.1016/j.eswa.2011.02.072

89. Lima Junior FR, Osiro L, Carpinetti LCR (2014) A comparison between fuzzy AHP and fuzzy TOPSIS methods to supplier selection. Appl Soft Comput J 21:194-209. https://doi.org/10. 1016/j.asoc.2014.03.014

90. Dikshit-Ratnaparkhi A, Bormane D, Ghongade R (2020) A novel entropy-based weighted attribute selection in enhanced multicriteria decision-making using fuzzy TOPSIS model for hesitant fuzzy rough environment. Complex Intell Syst. https://doi.org/ 10.1007/s40747-020-00187-8

91. Singh SP, Singh P (2018) A hybrid decision support model using axiomatic fuzzy set theory in AHP and TOPSIS for multicriteria route selection. Complex Intell Syst 4:133-143. https://doi.org/ 10.1007/s40747-018-0067-y

92. Roy PK, Shaw K (2021) Modelling a sustainable credit score system (SCSS) using BWM and fuzzy TOPSIS. Int J Sustain Dev World Ecol 00:1-14. https://doi.org/10.1080/13504509. 2021.1935360 
93. Prabhu M, Abdullah NN, Ahmed RR, Nambirajan T, Pandiyan S (2020) Segmenting the manufacturing industries and measuring the performance: using interval-valued triangular fuzzy TOPSIS method. Complex Intell Syst 6:591-606. https://doi.org/10.1007/ s40747-020-00157-0

94. Dağdeviren M, Yavuz S, Kilinç N (2009) Weapon selection using the AHP and TOPSIS methods under fuzzy environment. Expert Syst Appl 36:8143-8151. https://doi.org/10.1016/j.eswa.2008. 10.016

95. Hirschey M (1979) Fundamentals of managerial economics, 1st edn. The Macmillan Press Ltd, South-Western. https://doi.org/ 10.1007/978-1-349-16225-3

96. Pal D, Vanijja V, Papasratorn B (2015) An empirical analysis towards the adoption of NFC mobile payment system by the end user. Proc Comput Sci 69:13-25. https://doi.org/10.1016/j.procs. 2015.10.002

97. Sharma SK, Sharma M (2019) Examining the role of trust and quality dimensions in the actual usage of mobile banking services: an empirical investigation. Int J Inf Manag 44:65-75. https://doi.org/10.1016/j.ijinfomgt.2018.09.013

98. Arcand M, PromTep S, Brun I, Rajaobelina L (2017) Mobile banking service quality and customer relationships. Int J Bank Mark 35:1066-1087. https://doi.org/10.1108/ IJBM-10-2015-0150
99. Saka D, Putra K, Sadikin MA (2017) S-Mbank: secure mobile banking authentication scheme using signcryption, pair based text authentication, and contactless smart card. In: 15th Int. Conf. Qual. Res. Int. Symp. Electr. Comput. Eng., IEEE, Nusa Dua, Bali, Indonesia, pp 230-234. https://doi.org/10.1109/QIR.2017. 8168487

100. Aboutorab H, Saberi M, Asadabadi MR, Hussain O, Chang E (2018) ZBWM: the Z-number extension of Best Worst Method and its application for supplier development. Expert Syst Appl 107:115-125. https://doi.org/10.1016/j.eswa.2018.04.015

101. Singh S, Srivastava RK (2020) Understanding the intention to use mobile banking by existing online banking customers: an empirical study. J Financ Serv Mark 25:86-96. https://doi.org/ 10.1057/s41264-020-00074-w

102. Zarifopoulos M, Economides AA (2009) Evaluating mobile banking portals. Int J Mob Commun 7:66-90. https://doi.org/ 10.1504/IJMC.2009.021673

Publisher's Note Springer Nature remains neutral with regard to jurisdictional claims in published maps and institutional affiliations. 